\title{
Modern palynological record in the Bay of Brest (NW France): Signal calibration for palaeo-reconstructions
}

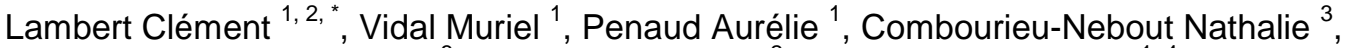 \\ Lebreton Vincent ${ }^{3}$, Ragueneau Olivier ${ }^{2}$, Gregoire Gwendoline ${ }^{1,4}$
}

${ }^{1}$ CNRS, Laboratoire Domaines Océaniques-LDO, IUEM-UBO, F-29280 Plouzané, France

${ }^{2}$ CNRS, Laboratoire des sciences de l'Environnement MARin-LEMAR, IUEM-UBO, F-29280 Plouzané, France

${ }^{3}$ CNRS, Département de Préhistoire, Museum National d'Histoire Naturelle, Paris, France

${ }^{4}$ IFREMER, Géosciences Marines, Centre de Brest, 29280 Plouzané, France

* Corresponding author : Clément Lambert, email address : clement.lambert@univ-brest.fr

\begin{abstract}
:
Modern palynological investigations (pollen and non-pollen palynomorphs) have been carried out for the first time in the entire Bay of Brest (BB; NW France), a semi-enclosed oceanic basin flooded during the Holocene that today is exposed to both marine (North Atlantic surface waters) and fluvial (Aulne and Elorn rivers) influences. Palynological analyses were conducted on 41 surface sediments collected in several mudded bays where low-energy conditions prevail, allowing for fine particle decantation, and also on 12 moss samples considered to be pollen rain collectors taken on the periphery of the BB. Furthermore, the BB allows a direct comparison between landscapes and fossilized pollen assemblages in sediments thanks to relatively small watersheds and well-studied vegetation cover on land. Our data display a well-known distortion between pollen taxa percentages calculated from palynological slides and current vegetation cover on land, with a particular overestimation of arboreal taxa as well as an underestimation of herbaceous ones, especially of cereal crops that represent a major component of the regional continental vegetation. Various factors may be involved, including pollen transport issues, taphonomic processes, and different pollination rates according to trees/herbaceous taxa. Under close examination, we find that while all surface sediments show the same major species, palynological maps established in the BB regarding some specific pollen taxa exhibit differences and upstream-downstream gradients. Also, the comparison between the pollen content in BB surface sediments and in mosses supports the hydrodynamic influence acting on the pollen distribution in sediments. More specifically, we suggest that some arboreal taxa reflect a watershed effect, especially Alnus, which seems to be highly correlated to river influences and could therefore be considered as a potential proxy for fluvial Holocene palaeo-discharges within the BB.
\end{abstract}




\section{Highlights}

- Modern palynological (pollen, dinocysts) investigations in a NW French estuary $>$ Distortion between pollen taxa percentages and vegetation cover estimated on land Overestimation (/underestimation) of tree (/herbaceous) taxa in marine sediments - Alnus as a potential proxy for fluvial Holocene palaeodischarge

Keywords : pollen, dinocysts, surface sediments, estuarine dynamics, vegetation cover 


\section{Introduction}

Coastal areas are highly sensitive to climatic variations and human pressures and may therefore be ideal sites to discuss palaeoenvironmental changes through time. In Brittany (NW France, NW Europe), a recent sedimentological study carried out in the Bay of Brest (BB) highlights high, modern (up to $0.2 \mathrm{~cm} /$ year) and Holocene, sedimentation rates (Gregoire et al., 2016); the BB thus offers a unique opportunity to explore palaeoenvironmental changes at a high temporal resolution over the last century (Klouch et al., 2016), as well as over the last 9 ky BP (Gregoire et al., 2016). Within this context, palynology has commonly been used during the last few decades to discuss past Holocene environmental reconstructions (e.g. Ritchie et al., 1985; Lézine and Casanova, 1989; Davis et al., 2003; Mauri et al., 2015). However, understanding present-day palynomorph deposits (organic microfossils mainly including pollen, spores, and cysts of dinoflagellates or dinocysts) in modern sediments is first required before any palynological-based palaeoecological reconstructions. Past studies based on modern pollen records underline a distortion between current vegetation cover in surrounding watersheds (studied by botanists, biogeographers) and preserved pollen grains in modern sediments (studied by palynologists, palaeoenvironmentalists), this distortion being explained by different factors such as pollen preservation (taphonomic processes) or pollen production rates (e.g. Smirnov et al., 1996; Brown et al., 2007; Zhao et al., 2009; Ganne et al., 2016). This pollinic bias has mainly been discussed in continental environments under different latitudes and climatic contexts (e.g. Ruffaldi, 1994, East of France; Gaillard et al., 1998, Sweden; Zhao et al., 2009, China) as well as in coastal-to-estuarine environments (e.g. Brush and DeFries, 1981 and Smirnov et al., 1996: both studies in North America, the Potomac and Mississippi rivers, respectively). More specifically, a recent study carried out in 
the Loire River evidenced a large homogeneity of the pollen content throughout the entire upstream-downstream transect (from the upper inner estuary to the river mouth) but a distortion between the arboreal pollen content in sediments (i.e. high percentages of Quercus and Pinus) and the scarcity of trees within the surrounding landscapes (Ganne et al. 2016). Also, in stratified estuarine environments, dinocysts have often been explored in parallel with pollen grains (e.g. Matsuoka et al., 1999, Chengjang river, China; Sildever et al., 2015, Baltic Sea; Ganne et al., 2016, Loire River, France), highlighting the mixed influence of marine and estuarine waters.

The aim of this study is to describe and understand for the first time the modern palynological signature (pollen and dinocysts) recorded within the BB through 41 surface sediments collected throughout the bay, in order to support future Holocene pollen investigations (Lambert, C., $\mathrm{PhD}$ ongoing). Also, in order to discuss aerial vs. river inputs and to identify different vegetation-types around the BB, 12 moss pollsters were collected from the periphery of the $\mathrm{BB}$, and their palynological contents were compared to those of the surface sediments. We then discuss some key issues regarding present-day palynomorph deposits, constituting relevant information for palynological calibration studies:

i) $\mathrm{BB}$ watersheds are relatively small and well circumscribed, avoiding long-distance pollen transport and related taphonomic processes, their vegetation cover being regularly studied by the National Botanical Conservatory of Brest. This favourable context allows for a direct comparison between pollen assemblages preserved in sediments and landscape maps built from the Corine Land Cover database. What are the main similarities and differences according to both palynological and botanical approaches? 
ii) Complex hydrodynamic features in an estuarine environment involve meteorological and current forcings (wind, wave, fluvial, and tidal forcings) that are able to disperse pollen grains and micro-algae over the BB. Distribution maps of major taxa will enable us to discuss if specific pollen distribution patterns are noticeable within the BB.

\section{Environmental settings}

\subsection{Geographical context}

The Bay of Brest is located in north-western Brittany (Fig. 1a) and represents a shallow semienclosed basin of $180 \mathrm{~km}^{2}$ surrounded by a $200 \mathrm{~km}$ long coastline. Its basement corresponds to Proterozoic igneous rocks in the north and Brioverian (Neoproterozoic, possibly Early Cambrian) to Palaeozoic (Ordovician, Devonian and locally Carboniferous) sediments in the south and east (Chauris and Plusquellec, 1980). Present-day low reliefs (few hills reach 330 m high) are inherited from the peneplanation of the Hercynian chain (Ballèvre et al., 2009). The department of Finistère has been subsident since the Eocene (Ziegler, 1992) and continued to sag slightly during the Holocene (Goslin, 2014; Goslin et al., 2015). The river system settled during the Tertiary (Hallegouet et al., 1994).

During the Quaternary, the BB was submitted to alternations of glacial lowstands, river valleys being subsequently deepened by erosive processes, and interglacial highstands characterized by sediment infilling of the bay; the last transgressive episode thus corresponding to a Holocene sedimentary fill of the BB (Gregoire et al., 2015). Bathymetry highlights submarine channels in the BB that attest to palaeo-fluvial systems (Fig. 1a: Gregoire et al., 2016). Palaeo-channels of the two main current rivers, the Aulne and the 
Elorn, are about 30 and $15 \mathrm{~m}$ deep respectively, and converge in the west at a trough of about $50 \mathrm{~m}$ deep (Troadec and Le Goff, 1997). Nevertheless, the depth of the bay does not exceed $10 \mathrm{~m}$ deep for approximately $60 \%$ of its surface (Monbet and Bassoulet, 1989).

Today, the BB is characterized by a macrotidal influence with a maximum tidal amplitude of $8 \mathrm{~m}$ (Troadec and Le Goff, 1997). Granulometry of modern sediments reflects specific hydrodynamic conditions mainly related to tidal currents (Fig. 1c) (Gregoire et al., 2016). In its western part, the BB is connected to Atlantic Ocean shelf waters through the "Goulet", a strait of about $1.8 \mathrm{~km}$ large and $50 \mathrm{~m}$ deep. Marine waters flow into the $\mathrm{BB}$ at each new tidal cycle with the current speed reaching $1.03 \mathrm{~m} / \mathrm{s}$, mainly S-E oriented. In the stream direction, sedimentation is mainly composed of sands and gravels (Gregoire et al., 2016). On either side of this axis, current speed is strongly reduced and grain-size of sediment is fine to very fine (silts and clays) with clays decantation in small bays (Troadec and Le Goff, 1997; Gregoire et al., 2016). The lack of interbedded sands or high energy sedimentary structures in these bays argues for in situ deposits, an assumption reinforced by ${ }^{210} \mathrm{~Pb}$ dating on surface sediments (Gregoire et al., 2015, 2016; Klouch et al., 2016). In its eastern part, the BB receives freshwater supplies from the Aulne, the Elorn, and from the smaller Daoulas River as well (Fig. 1a). The Aulne and Elorn outflows contribute to up to $85 \%$ of the total river discharges in the BB (Delmas and Treguer, 1983). BB watersheds (Fig. 2a) are characterized by 2,000 kilometers of waterways and most of their runoff flows into the BB through the Aulne River (114 km long, $1224 \mathrm{~km}^{2}$ of watershed, and $20.40 \mathrm{~m}^{3} / \mathrm{s}$ of annual debit) (Troadec and Le Goff, 1997). 


\subsection{Climatic context}

The BB and its watersheds are subjected to an oceanic climate characterized by mild temperatures (slight seasonal variations on the coastline and small daily temperature differences, with an average of $15^{\circ} \mathrm{C}$ in summer and around $7.5^{\circ} \mathrm{C}$ in winter, Fig. $1 \mathrm{~b}$ ), and high regular rainfalls (with an average of 200 rainy days/year in western Brittany and 800 to 1,000 mm/year measured in the BB, Troadec and Le Goff, 1997). Wind conditions show one dominant direction: mainly from the south-west in autumn and winter (Fig. 1b). North-east and north-west minor components can also appear during spring and summer (Troadec and Le Goff, 1997). Winds are characterized by a diurnal evolution due to local effects associated with the sea breeze. Wind speeds in Brittany can exceed $100 \mathrm{~km} / \mathrm{h}$ during 5 to 15 days per year, generating major storms and related erosion / submersion impacts depending on the coastal exposure (van Vliet-Lanoë et al., 2014). The climate of the BB, as in much of northern Europe, is subject to the North Atlantic Oscillation (NAO) configuration (Hurrell, 1995). This natural atmospheric variability is characterized by changes in atmospheric pressure anomalies between the Iceland Low and the Azores High. Negative NAO modes are characterized by weakened mid-latitude westerlies and colder and drier winters above Brittany with less storminess. Conversely, positive NAO modes induce mild and moist winter conditions with increasing storm activity (Cayan, 1992; Hurrell, 1995).

\subsection{Current vegetation cover on Finistère and BB watersheds}

The department of Finistère is one of the leading agricultural regions of France, with a cultivated and/or grazed surface of about 60\%, mainly with cereals (132 000 ha), forage (173,000 ha), and vegetable crops (23000 ha) (Quéré et al., 2008). Finisterian forests and 
woodlands present a low surface cover and are very fragmented with mainly small parcels and many hedgerows. They are divided into high forests (37.5\%), coppices under high forests (30\%), and coppices (32.5\%) (Quéré et al., 2008). Deciduous forests occupy 67\% of the woodlands with Quercus (mostly $Q$. robur) recorded as the predominant taxa (35.5\%), then followed by Salix (12.5\%; mostly S. atrocinerea, Castanea sativa (6.6\%), and Fagus sylvatica (6.3\%). Conifer plantations mainly consist of Pinus (mostly P. pinaster) and Picea sitchensis. The Finisterian Agriculture Chamber considers that "temporary grasslands", added to "always grassy areas", cover about $41 \%$ of the total agricultural surface of the department, reflecting the importance of cattle farming (Observatoire de l'agriculture du Finistère - Indicateurs de développement durable, 2015) (Fig. 2c-c'). Some wet heathlands and bogs are found in the hinterland.

At the scale of BB watersheds, Corine Land Cover (CLC, i.e. biophysical land cover database from the European Environment Agency; Aune-Lundberg and Strand, 2010) enables mapping of the different vegetation types encountered on the territory (Fig. 2a). A large majority of continental surfaces are dominated by farmlands, with cereal crops and vegetables, and often bordered by hedgerows (Fig. 2a). Geographic Information System (GIS) analysis applied to the CLC map allows us to express the vegetation cover in terms of land use percentages. Agricultural areas account for more than $75 \%$ (temporary and permanent grasslands account for $30.5 \%$ and crops for $44.5 \%$ ), forests and woodlands (including Quercus robur, Corylus avellana, Fagus sylvatica, Pinus pinaster, ...) for $11.6 \%$, moors and grasslands (including Poaceae, Ericaceae (Erica cinerea, E. ciliaris, E. tetralix, Calluna vulgaris), Ulex (europaeus and gallii species), Cytisus scoparius, Brassicaceae, Asteraceae, Ranunculaceae, Rosaceae ...) for $6.1 \%$, and coastal areas (cliffs with aerohalin grasslands, moors, as well as salt marshes: Chenopodiaceae, Plantago (lanceolata, coronopus, major, maritima species), 
Brassicaceae, Ulex, and Ericaceae, ...) for only $0.7 \%$ of the BB watersheds (Fig. 2b). These GIS estimates deduced from the CLC map are broadly consistent with the percentages issued from the Finisterian Agriculture Chamber, with a still larger proportion of cultivated areas in the BB watersheds (75\%) as compared to the entirety of Finistère (58\%, see Fig. $2 b-c)$.

\section{Methods}

\subsection{Sampling strategy}

\subsubsection{Marine surface sediments from the Bay of Brest}

In the BB, surface sediments often contain a large portion of biogenic concretions (maerl or Crepidula shells, named indifferently "gravels" in Table 1), preventing radiometric dating on the fine sediment fraction. These sediments, as well as coarse sediments found in the main axis of the BB channels (Gregoire et al., 2016), have thus been discarded from our palynological study which was only carried out on silty and clayey materials. Modern sediment samples from the BB have been studied by extracting the first five centimeters of 41 interface cores distributed over the shallowest parts of the BB (which represent more than $50 \%$ of the Bay), (Fig. 1a and Table 1) and retrieved during the SERABEQ-1 and AL-2013 drilling campaigns (IFREMER projects). Several core tops were dated using ${ }^{210} \mathrm{~Pb}$ and fall-out

${ }^{137} \mathrm{Cs}$ and their chronologies provided estimated sedimentation rates of about $0.15 \mathrm{~cm} /$ year (Gregoire et al., 2015; Klouch et al., 2016). Thus a maximum record of 30 to 40 years of sedimentation is expected whatever the sampling location.

\subsubsection{Mosses from the periphery of the Bay of Brest}


Moss pollsters are well-known as major traps for pollen rain (Faegri and Iversen, 1989). Bulk mosses have been used in palynology to accurately record the surrounding vegetation even if the representativeness of the vegetation cover through moss samples is still under discussion (Boyd, 1986; Gaillard et al., 1994; Ruffaldi, 1994; Hicks and Birks, 1996; Vermoere et al., 2000; Räsänen et al., 2004). Furthermore, the time elapsed during the deposition of pollen grains must be considered, mainly depending on large interannual variations in pollen productivity (Hicks et al., 2001), as well as moss types characterized by specific differential growth rates (Pitkin, 1975; Pakarinen and Tolonen, 1977; El-Daoushy et al., 1982; Sonesson et al., 2002). According to previous studies, mosses are assumed to record 1-2 years (Caseldine, 1981; Cundill, 1991) or up to 10-15 years (Crowder and Cuddy, 1973; Bradshaw, 1981; Mulder and Janssen, 1998) of pollen rain.

In our study, two moss samples of approximately $10 \mathrm{~cm}^{2}$ were collected in each of the 12 selected stations around the BB, near the coastline and far from urban areas (Fig. 1a and Table 2). Sampling stations were carefully selected in order to describe the real diversity of coastal environments, including shoreline cliffs ("Pointe du Diable", this location is rather anthropized), moors (“Fraternité”, "Pointe de Dinan”), hedgerows (“Quelern/Persuel”, Bay of Fret and "Pen Ar Vir"), forests ("Landévennec"), and fixed dunes ("Bay of Goulien"). Mosses can be divided into three parts: green shoots, brown shoots, and moss humus (Cundill, 1991). Only the moss (green and brown parts) is considered for pollen analyses, the soil fraction is excluded.

\subsection{Palynological study}

\subsubsection{Laboratory procedure}


Palynomorph extraction was performed at UMR 7194 CNRS (French National Museum of Natural History) on the $10-150 \mu \mathrm{m}$ fraction. Twelve moss samples were primarily crushed through a $150 \mu \mathrm{m}$ sieve with distilled water. The laboratory procedure for moss samples consisted of acetolysis (Erdtman, 1969). Forty-one BB marine surface sediments were analyzed following a standard protocol described by de Vernal et al. (1999) that includes 10\% $\mathrm{HCl}$ and $70 \% \mathrm{HF}$ to remove carbonate and siliceous fractions, respectively. Heavy liquid was also applied to remove particles with the highest density. In total, fifty three (41 surface sediments and 12 moss samples) final residues were mounted between slides and coverslips with glycerine jelly. Palynomorph concentrations were calculated through the marker grain method (Stockmarr, 1971; de Vernal et al., 1999; Mertens et al., 2009). This method consists of adding aliquot volumes of Lycopodium spores before the palynological treatment, these exotic spores being then counted in parallel with fossil palynomorphs.

\subsubsection{Palynological identification}

For each analyzed sample, 150 to 200 pollen grains have been identified following Faegri and Iversen (1989), Moore et al. (1991), and Reille (1995) and Beug (2004). Cereal crops (Cerealia-type) have been distinguished from total Poaceae through their $>45 \mu \mathrm{m}$ diameter and their $>10 \mu \mathrm{m}$ annulus pore size (Joly et al., 2007). The three species of Plantago occuring in our study area have been determined from palynological observations following Beug (2004). Because of their low palynomorph concentrations, a small number of samples contained between 100 and 150 pollen grains but were not discarded, according to Fatela and Taborda (2002). Sixty-five different taxa in total, with pollen, dinoflagellate cysts (dinocysts) and other non-pollen palynomorphs (e.g. spores, amoebas, freshwater and marine micro 
algaea, foraminiferal linings) were then identified in the sediments and mosses (Tables 3, 4) using a Leica DM 2500 at magnifications of X630 and X1000. Pollen percentages (assemblages) were calculated on a pollen sum that excludes spores and non-identified pollen, and pollen concentrations were expressed in number of pollen grains $/ \mathrm{cm}^{3}$ of dry sediment.

\section{Results}

\subsection{Marine surface sediments}

\section{$\underline{\text { 4.1.1 Pollen data }}$}

A total of 51 taxa have been identified in total in the BB sediments and taxa reaching percentages higher than $2 \%$ have been graphically depicted on a simplified pollen spectra (Fig. 3a). Average pollen concentrations are about 310,000 grains $/ \mathrm{cm}^{3}$ and pollen assemblages are characterized by similar major taxa (e.g. deciduous Quercus, Corylus, Pinus, Alnus, or Poaceae) whatever the study site considered in the BB (Fig. 3a). Trees, especially Quercus, Corylus, Pinus, and Alnus, are much more highly represented than herbaceous taxa. Other tree pollen grains were frequently counted but never exceeded $20 \%$, such as Castanea, Betula, and Ulmus. In addition to Poaceae, the most represented herbaceous taxa are Chenopodiaceae, Urticaceae, Brassicaceae, Cichorioideae, and Plantago spp. The occurrences of cereal crops ( $>45 \mu \mathrm{m}$ diameter) are scarce in BB sediments. Moreover, the overall low diversity (51 taxa) is probably related to the limited surface and uniformity of the BB watersheds (2,645 $\mathrm{km}^{2}$ in Troadec and Le Goff, 1997), as compared to other estuaries fed by major rivers and therefore draining large watersheds encompassing more varied environments (e.g. Loire watersheds in Ganne et al., 2016). A pie chart has thus been made to: i) summarize 
the four main vegetation groups of identified taxa (forest trees, riparian taxa, herbs, and cereal crops), and ii) average the obtained percentages for all samples in order to provide a general overview of vegetation types recorded within BB sediments (Fig. 4). As previously mentioned, trees are the dominant group (about 57\%), followed by herbaceous taxa (around 25\%), and riparian forest (around 10\%), while cereal crops only represent $1 \%$ of pollen assemblages.

\subsubsection{Dinoflagellate cyst data}

In addition to pollen grains, dinocysts were counted on the same palynological slides. A total of 15 different taxa were identified (Fig. 5a). Dinocyst concentrations are low (mean values of $20,600 \mathrm{cysts} / \mathrm{cm}^{3}$ ), with an average of 11 specimens and a maximum diversity of six taxa per slide. Contrary to pollen data, dinocyst assemblage and spatial distribution interpretations are therefore doubtful. Nevertheless, the main taxa (Lingulodinium machaerophorum, Operculodinium centrocarpum, Spiniferites membranaceus, Spiniferites ramosus, Spiniferites belerius, Spiniferites delicatus, Spiniferites bentorii, Spiniferites mirabilis, cysts of Pentapharsodinium dalei, and Selenopemphix quanta) can be expressed in concentrations $\left(\right.$ cysts $\left./ \mathrm{cm}^{3}\right)$. Also, the distribution of total cyst concentrations in BB sediments can be mapped (Fig. 5b), highlighting the highest values in the center of the $\mathrm{BB}$, aligned with the river axis (i.e. aligned with main freshwater inputs bringing nutrients to the BB) but outside main bottom channels where currents are stronger. In these areas, dinocyst assemblages comprise species typical for estuarine conditions, i.e. consisting in taxa characterizing freshwaterrelated / stratified habitats (L. machaerophorum; Morzadec-Kerfourn, 1977, 1979) as well as 
taxa related to fully marine conditions (S. ramosus, O. centrocarpum; Morzadec-Kerfourn, 1977, 1979).

\subsection{Mosses}

A total of 50 pollen taxa were recognized, including 14 arboreal taxa (mainly Quercus, Corylus, Fagus, Betula, and Castanea) and 32 herbaceous ones (mainly Brassicaceae, Asteraceae, Poaceae, Ericaceae, Rosaceae, and Plantago determined at the species level: $P$. maritima type, $P$. coronopus type, $P$. lanceolata type), cereal crops, and few aquatic plants (Fig. 3b).

Besides Quercus occurring in all samples, pollen spectra are different depending on the environment surrounding the sampling station, therefore exhibiting some characteristic taxa. Indeed, the dune-type area (station: Bay of Goulien) is mainly characterized by Brassicaceae pollen, and to a lesser extent by other herbaceous taxa such as Cichorioideae, Asteroideae, Ranunculaceae, Fabaceae (Trifolium type), Poaceae, and finally Pinus and Quercus. Poaceae and Ericaceae both represent a significant part of the pollen content in moor environments (stations: "Pointe du Diable", "Pointe de Dinan" 1 \& 2) where Plantago maritima is recognized and Ulex is a noticeable component in more advanced moors (station: FraternitéRoscanvel). Hedgerow meadows (stations: Quelern-Persuel, Bay of Fret, Pen Ar Vir, Keramenez, Kernizi) are characterized by Quercus, Corylus, and many Poaceae including Rosaceae, Asteraceae, Ranunculaceae, and Caryophyllaceae. As expected, forest environments around the BB (stations: Bay of Poulmic and Landevennec forest) are marked by large amounts of tree pollen (around 60\%; Pinus, Quercus, Fagus, Corylus, Betula). 
In addition to pollen, a few NPP, particularly several amoebas (Euglypha and Cyclopyxis), were identified that were especially present in large numbers in the mosses collected in hedgerow and forest environments.

\section{Discussion}

\subsection{Mosses: pollen collectors of surrounding vegetation}

As described above, pollen content in mosses is characterized by the occurrence of specific taxa (e.g. Ericaceae, Plantago spp) or the high abundance of some of them (Quercus, Pinus, Poaceae) related to their close environment. Nevertheless, representativeness of the different vegetation-type groups worked out from the continental vegetation cover, in mosses and modern sediments highlights distortions in the pollen record. The average of pollen grain percentages in all mosses shows a high proportion of tree taxa $(39.1 \%$; Fig. 4) when compared with the low forest cover characterizing BB watersheds (11.6\%, cf. Figs. 2a-b). The riparian forest taxa are poorly represented within mosses (1.4\%, Fig. 4), since most of analyzed mosses have been retrieved in coastal environments (dune backs, coastal lawns or cliffs and moorlands, mainly characterized by herbaceous taxa such as Ericaceae, P. coronopus, Brassicaceae, Caryophyllaceae, or Apiaceae) away from wetland and river environments. Moreover, the quasi-absence of salt meadow species is due to the non-sampling of saline environments (schorres and supratidal zones) which correspond to the ecological preferences of halophytes (such as Chenopodiaceae including Salicornia, Beta maritima, Halimione, Atriplex...). 
While many agricultural areas are found around the BB (Fig. 2a-b), pollen grains of cereal taxa are always rare in mosses $(0.8 \%$ of the total average, Fig. 4$)$, even when the surroundings correspond to agricultural environments (cf. Keramenez in the south of the Plougastel Peninsula; Fig. 1a). Scarcity of crops indicators is probably enhanced in our study by the sampling itself that has been done away from anthropic and agricultural areas, but can be mainly explained by the low dispersion of these pollen grains (Sjögren et al., 2015). Nevertheless, these imperfections excepted, the analysis of the pollen content trapped in mosses suggests that they record local vegetation from a narrow surrounding area around the collection site.

In modern BB sediments, pollen grain deposition shows the same taxonomic diversity but with very different values than in mosses, related to other processes (tidal dynamics, fluvial inputs, taphonomic processes ...). Taking into account the relative stability of the surrounding vegetation cover during the last decades (National Botanical Conservatory of Brest, oral comm.) and the last mapping data set updated in 2006 for the studied area (Corine Land Cover 2006), the recorded time difference in mosses (1-2 to 10-15 years) and sediments (about 30 years) cannot be invoked to explain differences observed between pollen spectra recorded in mosses and those of sediments. For example, the proportion of tree taxa pollen in mosses is $39.1 \%$ compared to $57.3 \%$ in BB sediment samples. Accordingly, herbaceous taxa display an opposite proportion with $57.1 \%$ in mosses and $25.5 \%$ in sediments, highlighting once more the low transport of herbaceous pollen grains (which are mostly entomophilous whereas trees are rather anemophilous). Moreover, while riparian forest taxa show low percentages in mosses (1.4\%; Fig.4), they are over-represented in BB sediments (9.8\%; Fig.4). Indeed, while pollen grains trapped in mosses mainly result from aerial transport, pollen grains fossilized in the $\mathrm{BB}$ are mainly transported by rivers, keeping in mind that 
dominant winds blow from the ocean to the continent (Fig. 1b) and do not represent an important source of pollen grains in the BB. Considering amoebas, their noticeable occurrence in mosses, especially those collected in forest environments, compared to their quasi-absence in sediment samples underline their continental relationship. The comparison between pollen data obtained in mosses and marine sediments highlights the requirement to characterize the modern distribution of pollen grains within the whole $\mathrm{BB}$ in order to understand the present-day underlying forcing mechanisms on pollen fossilization. This will then allow us to better interpret past vegetation dynamics during the Holocene through sediment cores retrieved in the BB.

\subsection{Understanding the overall distribution of pollen grains in modern BB sediments}

\subsubsection{Over- and under-representation of arboreal and herbaceous pollen taxa}

Average pollen grain proportions in modern sediments (Fig. 4) show that arboreal taxa are well represented in BB sediments (around 50-60\%), whatever the studied sample (Figs. 3a and 4a), while values recorded in mosses are around $40 \%$ (with significant differences according to sampled sites, Figs. $3 b$ and $4 b$ ). This result highly differs from the $12 \%$ (Fig. $2 b$ ) of continental surface covered by forests on BB watersheds through CLC. A similar result has been shown further south in the Loire estuary by Ganne et al. (2016). Trees (especially Corylus and Quercus) are major components of hedgerow meadows and forested environments in BB sediments, arboreal pollen grains of both environments are considered together in this study while the hedgerow meadows group is embedded in "cultivated areas" in CLC (cf. Fig. 2a). This different way to group pollen taxa could then artificially enhance 
the distortion between tree pollen percentages estimated in BB sediments and calculated from regional CLC map of the vegetation cover (Fig. 2a). Also, the over-representation of arboreal taxa in sediments can be due to transportation issues. Indeed, studies quantifying pollen grains in the atmosphere showed that tree pollen grains are better represented than any other pollen taxa (Romano et al., 1988; Xu, 1993). Furthermore, arboreal pollen production is higher than that of herbaceous plants (Broström et al., 2008; Mazier et al., 2015; Sjögren et al., 2015). Finally, taphonomy issues may be involved; pollen grains of some trees being well preserved during fossilization due to their higher resistance to oxidation processes (Lebreton et al., 2010).

Generally, herbaceous taxa percentages, especially cerealia pollen grains (1\%), are extremely low in BB sediments, compared to open, especially agricultural, areas that are largely predominant on the BB watersheds (around $40 \%$ of temporary grasslands or wastelands, Fig. 2b-c). It has indeed been shown that Poaceae pollen grains generally undergo little transportation and further are produced in small amounts relative to tree pollen grains (Broström et al., 2008; Sjögren et al., 2015). Pollen dispersion and productivity can therefore explain the bias between vegetation cover and modern palynological records in BB sediments (Prentice, 1985; Sugita, 1994). More specifically, aerohalin grasslands, moors (e.g. Ericaceae, Ulex) and halophytic vegetation (e.g. Chenopodiaceae) are major vegetation components of the Atlantic Coast. Their scarcity in modern BB sediments can partly be explained by the fact that they only cover a low surface in continental surroundings (Fig. 2a-b). Consequently, a strong representation in any fossil sequences will probably suggest a strong influence of salty environments and coastal marshes in the studied site. However, it is important to note that most of their components (e.g. Caryophyllaceae, Chenopodiaceae) also have ruderal ecological preferences. Finally, ruderal and adventitious pollen are commonly used to discuss 
past human agricultural practices since the Neolithic (e.g. Fernane et al., 2014). Their general underrepresentation in modern BB sediments must be kept in mind when considering Holocene palynological records and a small representation of these taxa in Holocene pollen assemblages will therefore be particularly significant, especially if coupled with other tenuous anthropogenic markers.

\subsubsection{Specific distribution patterns of selected pollen taxa and palaeo-ecological significances}

Despite an evident homogeneity in pollen taxa distribution that could be attributed to estuarine hydrodynamics mixing suspended materials within the BB (Pommepuy et al., 1979), different specific patterns can be observed when taxa are considered independently in their

maximum range of percentages calculated for all BB modern sediments (Fig. 6). Maps have been produced for selected taxa so as to highlight specific characteristics inherent to each of them, providing useful information for addressing future Holocene palaeo-ecological interpretations in the $\mathrm{BB}$.

\section{Quercus and Corylus}

Tree pollen grains show a relatively uniform distribution pattern within the BB. However, Corylus percentages are slightly higher close to river mouths (particularly the Aulne), while the distribution of Quercus percentages shows slightly higher values in the south of the Plougastel Peninsula (Fig. 6). Corylus - and Castanea - spread widely in the southern BB, mainly stem from the Aulne and Daoulas watersheds which are characterized by richer soils (sedimentary basement). In contrast, the Elorn and Penfeld watersheds are characterized by 
poorer soils (igneous rock basement) (Troadec and Le Goff, 1997). Taking into account the fact that Quercus is an acidophilous species, and Corylus is preferentially located on richer soils, a watershed effect may be responsible for the distribution of pollen taxa (Tarakcioglu et al., 2003; Szymura and Szymura, 2013).

\section{Poaceae and cereal crops}

All Poaceae taxa (Poaceae and crop pollen grains) are found rather uniformly in the BB, with a slight increase noted close to main river outflows (Fig. 6). The low mean percentages of these taxa in present-day BB sediments lead us to consider that a lack of crop pollen in Holocene pollen records does not necessary indicate the absence of agriculture practices on land. Besides, the fact that crop pollen grains are rather obviously distributed at river mouths, and particularly at the Daoulas one, suggests that anthropic signals will be more easily trapped by Holocene sediment cores located close to main BB Rivers.

\section{Alnus and Potamogeton}

Alnus, as well as Potamogeton (freshwater plant), are unevenly recorded in BB sediments, with the highest percentages found in the eastern $\mathrm{BB}$ close to the main river mouths (Elorn, Daoulas, and Aulne; Fig. 6). Although riparian forests are rare on BB watersheds, riparian taxa (mainly including Alnus) are well represented in present-day BB sediments (around 10\%; cf. Fig. 4). Significant abundances of these taxa may be related to good preservation in sediments since these pollen grains are known to be quite resistant to oxidation processes (Havinga, 1967; Campbell, 1999; Lebreton et al., 2010). Alnus pollen grain distribution close 
to river mouths leads us to consider this taxon as mainly transported by rivers and therefore as a potential proxy for fluvial discharges in Holocene palaeoenvironmental studies carried out in the $\mathrm{BB}$, such as also recently suggested in Holocene sequences retrieved in the Loire (Ganne, A, PhD ongoing).

\section{Pinus}

Pinus displays a distribution pattern opposite to that of cereal crops, being principally found close to the "Goulet", i.e. in the western BB towards the Atlantic Ocean, while percentages are obviously very low close to river mouths (Fig. 6). Since this pollen is often related to a more efficient transportation under aeolian currents (Tauber, 1967; Mudie, 1982; Niklas, 1985; Rousseau et al., 2008), prevailing westerly winds cannot explain its distribution within the BB. Since Poaceae and Alnus dominate the eastern inner part of the BB, it tends to generate a decreasing gradient in Pinus percentages from west to east. We may therefore suggest a relationship between Pinus increases and lower fluvial / higher marine influences in the BB. The absence of Picea pollen in pollen spectra, while plantations exist in the surrounding coniferous forests, can be explained by the large size of these pollen grains affected by rapid settling as well as by the low pollination rates of these trees (Eisenhut, 1961; Sugita et al., 1999). 


\section{Conclusion}

The present-day comparative analysis of pollen assemblages as recorded in Bay of Brest (BB) marine surface sediments and in mosses, with the vegetation cover characterizing the current hinterland of $\mathrm{BB}$ watersheds, provides essential information on how to accurately interpret palynological signals in the studied area. While pollen records from mosses are representative of the environment surrounding sampled sites, pollen data from BB sediments provides more regional information related to fluvial processes and current influences. More specifically, we highlight a strong distortion between forests that are over-estimated and open areas that are under-estimated in pollen records, with an especially clear under-representation of cereal crops. Moreover, despite certain homogeneity in pollen percentages recorded in BB sediments probably resulting from $\mathrm{BB}$ hydrodynamics, some gradients can be depicted within the maximum ranges of percentages of some taxa. Subsequently, Alnus distribution in the BB appears linked with fluvial dynamics, being closer to river mouths, and may thus represent an adequate proxy for Holocene palaeo-fluvial discharges, while Pinus appears linked with marine inflows and outflows within the BB. These palynological observations will therefore lead us to better interpret past vegetation dynamics in this complex BB estuarine system, and also highlight the difficulty in reconstructing land use by human activities through pollen indexes from marine sediments. These hypotheses will be considered later on: i) for the last century at an annual timescale resolution in a core retrieved close to the Daoulas river, and ii) for the last 9,000 years BP at a multidecadal timescale resolution with several long cores retrieved in the $\mathrm{BB}$, this bay representing a favorable study case for understanding Holocene climatic and anthropic forces operating there at a regional scale. 


\section{Acknowledgments}

This study was supported by the French CNRS and is a contribution to the 2015-2016 INSU project: "CAMOMI : Convergences / Approches croisées des signaux MOléculaires et MIcropaléontologiques pour décrypter les forçages anthropiques et climatiques en milieu côtier (Rade de Brest)". This work was supported by the «Laboratoire d'Excellence» LabexMER (ANR-10-LABX-19) and co-funded by a grant from the French government under the program «Investissements d'Avenir». We thank UMR 7194 CNRS (French National Museum of Natural History) for welcoming C. Lambert for palynological laboratory procedures, and IFREMER (Marine Geosciences, Plouzané) for their help in recovering all modern surface sediments in the Bay of Brest, especially during the SERABEQ cruises. We also want to thank the National Botanical Conservatory of Brest (and Particularly M. Hardegen and S. Magnanon), for all discussions about the distribution of present day vegetation on the Bay of Brest watersheds. Finally, we would like to thank Katalin Kovacs for the English improvements and we are particularly thankful to an anonymous reviewer for many helpful remarks improving the manuscript. 


\section{References}

Aune-Lundberg, L., Strand, G.-H., 2010. CORINE Land Cover 2006 - The Norwegian CLC2006 Project. Report from Norwegian Forest Landscape Institute, 11, pp. 14.

Ballèvre, M., Bosse, V., Ducassou, C., Pitra, P., 2009. Palaeozoic history of the Armorican Massif: models for the tectonic evolution of the suture zones. C.R. Geoscience. 341, 174-201.

Beug, H.J., 2004. Leitfaden der Pollenbestimmung für Mitteleuropa und angrenzende Gebiete. Verlag Friedrich Pfeil, Munich, pp. 542.

Boyd, W.E., 1986. Vegetation history at Linwood Moss, Renfrewshire, Central Scotland. J. Biogeogr. 207-223.

Bradshaw, R.H., 1981. Modern pollen-representation factors for woods in south-east England. J. Ecol. 45-70.

Broström, A., Nielsen, A.B., Gaillard, M.-J., Hjelle, K., Mazier, F., Binney, H., Bunting, J., Fyfe, R., Meltsov, V., Poska, A., 2008. Pollen productivity estimates of key European plant taxa for quantitative reconstruction of past vegetation: a review. Veg. Hist. Archaeobotany 17, 461-478.

Brown, A.G., Carpenter, R.G., Walling, D.E., 2007. Monitoring fluvial pollen transport, its relationship to catchment vegetation and implications for palaeoenvironmental studies. Rev. Palaeobot. Palynol. 147, 60-76.

Brush, G.S., DeFries, R.S., 1981. Spatial distributions of pollen in surface sediments of the Potomac estuary. Limnol. Oceanogr. 26, 295-309. 
Campbell, I.D., 1999. Quaternary pollen taphonomy: examples of differential redeposition and differential preservation. Palaeogeogr. Palaeoclimatol. Palaeoecol. 149, 245-256.

Caseldine, C.J., 1981. Surface pollen studies across Bankhead Moss, Fife, Scotland. J. Biogeogr. 7-25.

Cayan, D.R., 1992. Latent and sensible heat flux anomalies over the northern oceans: The connection to monthly atmospheric circulation. J. Clim. 5, 354-369.

Chauris, L., Plusquellec, Y., (coord) 1980. Carte Geol. France (1/50 000), feuille Brest (274). Ed. B.R.G.M., Orléans.

Crowder, A.A., Cuddy, D.G., 1973. Pollen in a small river basin: Wilton Creek, Ontario. In: Birks, H.J.B., West, R.G. (Eds.), Quaternary Plant Ecology. Blackwell Oxford, pp. 61-78.

Cundill, P.R., 1991. Comparisons of moss polster and pollen trap data: a pilot study. Grana 30, 301-308.

Davis, B.A., Brewer, S., Stevenson, A.C., Guiot, J., 2003. The temperature of Europe during the Holocene reconstructed from pollen data. Quat. Sci. Rev. 22, 1701-1716.

de Vernal, A., Henry, M., Bilodeau, G., 1999. Techniques de préparation et d'analyse en micropaléontologie. Les Cahiers du GEOTOP 3, 1-31.

Delmas, R., Treguer, P., 1983. Evolution saisonnière des nutriments dans un écosystème eutrophe d'Europe occidentale (la rade de Brest). Interactions marines et terrestres. Oceanol. Acta 6, 345-356.

Eisenhut, G., 1961. Untersuchungen über die Morphologie und Ökologie der Pollenkörner heimischer und fremdländischer Waldbäume. Forstwissenschaftliche Forschungen 15, 1-68. 
El-Daoushy, F., Tolonen, K., Rosenberg, R., 1982. Lead 210 and moss-increment dating of two Finnish Sphagnum hummocks. Nature 296, 429-431.

Erdtman, G., 1969. Handbook of Palynology. Morphology - Taxonomy - Ecology. An Introduction to the Study of Pollen Grains and Spores. Verlag Munksgaard, Copenhagen, pp. 486.

Faegri, K., Iversen, J., (Eds.) 1989. Textbook of pollen analysis. 4th Edition by Faegri, K., Kaland, PE \& Krzywinski, K.. John Wiley and Sons, Chichester, pp. 328.

Fatela, F., Taborda, R., 2002. Confidence limits of species proportions in microfossil assemblages. Mar. Micropaleontol. 45, 169-174.

Fernane, A., Gandouin, E., Penaud, A., Van Vliet-Lanoë, B., Goslin, J., Vidal, M., Delacourt, C., 2014. Coastal palaeoenvironmental record of the last $7 \mathrm{kyr}$ BP in NW France: Submillennial climatic and anthropic Holocene signals. The Holocene 24, 1785-1797.

Gaillard, M.-J., Birks, H.J.B., Emanuelsson, U., Karlsson, S., Lageras, P., Olausson, D., 1994. Application of modern pollen/land-use relationships to the interpretation of pollen diagramsreconstructions of land-use history in south Sweden, 3000-0 BP. Rev. Palaeobot. Palynol. 82, $47-73$.

Gaillard, M.-J., Birks, H.J.B., Ihse, M., Runborg, S., 1998. Pollen/landscape calibrations based on modern pollen assemblages from surface-sediment samples and landscape mappinga pilot study in South Sweden. In: Gaillard M.-J., Berglund B.E., Frenzel B., Huckriede U. (Editors), Quantification of land surfaces cleared of forests during the Holocene, Paläoklimaforschung/Palaeoclimate Research, Fischer Verlag, Stuttgart 27, 31-52 
Ganne, A., Leroyer, C., Penaud, A., Mojtahid, M., 2016. Present-day palynomorph deposits in an estuarine context: The case of the Loire Estuary. Journal of Sea Research, 118, 35-51.

Goslin, J., 2014. L'évolution du niveau marin relatif le long des côtes du Finistère (Bretagne, France) de 8000 BP à l'actuel: entre dynamiques régionales et réponses locales. Unpublished PhD Thesis, IUEM, Brest University, 14 February 2014, pp. 355.

Goslin, J., van Vliet Lanoë, B., Spada, G., Bradley, S., Tarasov, L., Neill, S., Suanez, S., 2015. A new Holocene relative sea-level curve for western Brittany (France): Insights on isostatic dynamics along the Atlantic coasts of north-western Europe. Quat. Sci. Rev. 129, $341-365$.

Gregoire, G., Ehrhold, A., Le Roy, P., Jouet, G., Garlan, T., 2016. Modern morphosedimentological patterns in a tide-dominated estuary system: the Bay of Brest (west Britanny, France). Journal of Maps 12, 1152-1159.

Gregoire, G., Schmidt, S., Ehrhold, A., Jouet, G., Le Roy, P., Garlan, T., Creignou, A., 2015. Enregistrement des conditions hydro-sédimentaires holocènes sur les zones bordières d'un système estuarien complexe abrité : La Rade de Brest (Finistère). $15^{\text {ème }}$ congrès français de Sédimentologie ASF, 13-15 Octobre 2015, Chambéry (France).

Hallegouet B., Lozac'h G., Vigouroux F. 1994. Formation de la Rade de Brest. In Corlay, J.P., (coord.) Atlas permanent de la Mer et du Littoral $\mathrm{n}^{\circ} 1$. Université de Nantes. CNRS-URA904/EDITMAR. p. 21.

Havinga, A.J., 1967. Palynology and pollen preservation. Rev. Palaeobot. Palynol. 2, 81-98. 
Hicks, S., Birks, H.J.B., 1996. Numerical analysis of modern and fossil pollen spectra as a tool for elucidating the nature of fine-scale human activities in boreal areas. Veg. Hist. Archaeobotany 5, 257-272.

Hicks, S., Tinsley, H., Huusko, A., Jensen, C., Hättestrand, M., Gerasimides, A., Kvavadze, E., 2001. Some comments on spatial variation in arboreal pollen deposition: first records from the Pollen Monitoring Programme (PMP). Rev. Palaeobot. Palynol. 117, 183-194.

Hurrell, J.W., 1995. Decadal trends in the North Atlantic Oscillation: regional temperatures and precipitation. Science 269, 676-679.

Joly, C., Barillé, L., Barreau, M., Mancheron, A., Visset, L., 2007. Grain and annulus diameter as criteria for distinguishing pollen grains of cereals from wild grasses. Rev. Palaeobot. Palynol. 146, 221-233.

Klouch, K., Schmidt S., Andrieux-Loyer F., Le Gac M., Hervio-Heath D., Qui-Minet Z.N., Quéré J., Bigeard E., Guillou L., Siano R., 2016. Historical records from dated sediment cores reveal the multidecadal dynamic of the toxic dinoflagellate Alexandrium minutum in the Bay of Brest (France). FEMS Microbiol. Ecol., 92, 1-16.

Lebreton, V., Messager, E., Marquer, L., Renault-Miskovsky, J., 2010. A neotaphonomic experiment in pollen oxidation and its implications for archaeopalynology. Rev. Palaeobot. Palynol. 162, 29-38.

Lézine, A.-M., Casanova, J., 1989. Pollen and hydrological evidence for the interpretation of past climates in tropical West Africa during the Holocene. Quat. Sci. Rev. 8, 45-55. 
Matsuoka, K., Saito, Y., Katayama, H., Kanai, Y., Chen, J., Zhou, H., 1999. Marine palynomorphs found in surface sediments and a core sample collected from off Changjiang River, western part of the East China Sea, in: The East China Sea. Proceedings of the Second Workshop on Oceanography and Fisheries in the East China Sea, Nagasaki, Japan, 25-26 Nov. 1999, 195-207.

Mauri, A., Davis, B.A.S., Collins, P.M., Kaplan, J.O., 2015. The climate of Europe during the Holocene: a gridded pollen-based reconstruction and its multi-proxy evaluation. Quat. Sci. Rev. 112, 109-127.

Mazier, F., Broström, A., Bragée, P., Fredh, D., Stenberg, L., Thiere, G., Sugita, S., Hammarlund, D., 2015. Two hundred years of land-use change in the South Swedish Uplands: comparison of historical map-based estimates with a pollen-based reconstruction using the landscape reconstruction algorithm. Veg. Hist. Archaeobotany 24, 555-570.

Mertens, K.N., Verhoeven, K., Verleye, T., Louwye, S., Amorim, A., Ribeiro, S., Deaf, A.S., Harding, I.C., De Schepper, S., González, C., 2009. Determining the absolute abundance of dinoflagellate cysts in recent marine sediments: the Lycopodium marker-grain method put to the test. Rev. Palaeobot. Palynol. 157, 238-252.

Monbet, Y., Bassoulet, P., 1989. Bilan des connaissances océanographiques en rade de Brest. Rapport CEA/IPSN, code DERO/EL 89-23. IFREMER-DEL-BP 70-29280 Plouzane, France, $106 \mathrm{pp}$.

Moore, P.D., Webb, J.A., Collinson, M.E., 1991. Pollen analysis. $2^{\text {nd }}$ Edition. Blackwell Scientific Publications, Oxford, 216 pp. 
Morzadec-Kerfourn, M.-T., 1977. Les kystes de dinoflagellés dans les sédiments récents le long des côtes Bretonnes. Rev. Micropaleontol. 20, 157-166.

Morzadec-Kerfourn, M.T., 1979. Les kystes de Dinoflagellés. Géologie Méditerranéenne 6, $221-246$.

Mudie, P.J., 1982. Pollen distribution in recent marine sediments, eastern Canada. Can. J. Earth Sci. 19, 729-747.

Mulder, C., Janssen, C.R., 1998. Application of Chernobyl caesium-137 fallout and naturally occurring lead-210 for standardization of time in moss samples: recent pollen-flora relationships in the Allgäuer Alpen, Germany. Rev. Palaeobot. Palynol. 103, 23-40.

Niklas, K.J., 1985. The aerodynamics of wind pollination. Bot. Rev. 51, 328-386..

Pakarinen, P., Tolonen, K., 1977. Distribution of lead in Sphagnum fuscum profiles in Finland. Oikos, 28, 69-73.

Pitkin, P.H., 1975. Variability and seasonality of the growth of some corticolous pleurocarpous mosses. J. Bryol. 8, 337-356.

Pommepuy, M., Manaud, F., Monbet, Y., Allen, G., Salomon, J.-C., Gentien, P., L'Yavang, J., 1979. Etude océanographique appliquée au S.A.U.M. de la rade de Brest, in: Les Côtes Atlantiques d'Europe, Évolution, Aménagement, Protection-Brest, France, 15-16 Mai 1979. Publications du CNEXO, Actes de colloques, 9, 211-226.

Prentice, I.C., 1985. Pollen representation, source area, and basin size: toward a unified theory of pollen analysis. Quat. Res. 23, 76-86. 
Quéré, E., Magnanon, S., Ragot, R., Gager, L., Hardy, F., 2008. Atlas floristique de Bretagne: la flore du Finistère. Ed. Siloë, 693 pp.

Räsänen, S., Hicks, S., Odgaard, B.V., 2004. Pollen deposition in mosses and in a modified "Tauber trap" from Hailuoto, Finland: what exactly do the mosses record? Rev. Palaeobot. Palynol. 129, 103-116.

Reille, M., 1995. Pollen et spores d'Europe et d'Afrique du Nord: supplement 1. Laboratoire de Botanique Historique et Palynologie, Marseille, 327 pp.

Ritchie, J.C., Eyles, C.H., Haynes, C.V., 1985. Sediment and pollen evidence for an early to mid-Holocene humid period in the eastern Sahara. Nature 314, 352-355.

Romano, B., Mincigrucci, G., Frenguelli, G., Bricchi, E., 1988. Airborne pollen content in the atmosphere of central Italy (1982-1986). Experientia 44, 625-629.

Rousseau, D.-D., Schevin, P., Ferrier, J., Jolly, D., Andreasen, T., Ascanius, S.E., Hendriksen, S.-E., Poulsen, U., 2008. Long-distance pollen transport from North America to Greenland in spring. J. Geophys. Res. Biogeosciences 113, 1-10.

Ruffaldi, P., 1994. Relationship between recent pollen spectra and current vegetation around the Cerin peat bog (Ain, France). Rev. Palaeobot. Palynol. 82, 97-112.

Sildever, S., Andersen, T.J., Ribeiro, S., Ellegaard, M., 2015. Influence of surface salinity gradient on dinoflagellate cyst community structure, abundance and morphology in the Baltic Sea, Kattegat and Skagerrak. Estuar. Coast. Shelf Sci. 155, 1-7. 
Sjögren, P., van der Knaap, W.O., van Leeuwen, J.F., 2015. Pollen dispersal properties of Poaceae and Cyperaceae: First estimates of their absolute pollen productivities. Rev. Palaeobot. Palynol. 216, 123-131.

Smirnov, A., Chmura, G.L., Lapointe, M.F., 1996. Spatial distribution of suspended pollen in the Mississippi River as an example of pollen transport in alluvial channels. Rev. Palaeobot. Palynol. 92, 69-81.

Sonesson, M., Carlsson, B. A, Callaghan, T.V., Halling, S., Björn, L.O., Bertgren, M., Johanson, U., 2002. Growth of two peat-forming mosses in subarctic mires: species interactions and effects of simulated climate change. Oikos 99, 151-160.

Stockmarr, J., 1971. Tablets with spores used in absolute pollen analysis. Pollen et Spores, 13, 615-621.

Sugita, S., 1994. Pollen representation of vegetation in Quaternary sediments: theory and method in patchy vegetation. J. Ecol., 82, 881-897.

Sugita, S., Gaillard, M.-J., Broström, A., 1999. Landscape openness and pollen records: a simulation approach. The Holocene 9, 409-421.

Szymura, T.H., Szymura, M., 2013. Spatial variability more influential than soil $\mathrm{pH}$ and land relief on thermophilous vegetation in overgrown coppice oak forest. Acta Soc. Bot. Pol. 82 (1), 5-11.

Tarakçioğlu, C., Yalçin, A., Bayrak, A., Küçük, M., Karabacak, H., 2003. Evaluation of nutritional status of hazelnut (Corylus avellana L.) grown in Ordu district by soil and plant analysis. Journal of Agricultural Sciences, Ankara Univ. (in Turkish), 9: 13-22. 
Tauber, H., 1967. Investigations of the mode of pollen transfer in forested areas. Rev. Palaeobot. Palynol. 3, 277-286.

Troadec, P., Le Goff, R., 1997. Etat des lieux et des milieux de la rade de Brest et de son bassin versant. Phase Préliminaire du Contrat Baie Rade Brest. Edition Communauté Urbaine de Brest, 335 pp.

van Vliet-Lanoë, B., Goslin, J., Hallégouët, B., Hénaff, A., Delacourt, C., Fernane, A., Franzetti, M., Le Cornec, E., Le Roy, P., Penaud, A., 2014. Middle-to late-Holocene storminess in Brittany (NW France): Part I-morphological impact and stratigraphical record. The Holocene, 24, 4, 434-453.

Vermoere, M., Vanhecke, L., Waelkens, M., Smets, E., 2000. A comparison between modern pollen spectra of moss cushions and Cundill pollen traps. Grana 39, 146-158.

$\mathrm{Xu}$, J., 1993. Studies on atmosphere spores and pollen and their influences on the sporpollen assemblages in the sediments of Huanghai sea. Acta Bot. Sin. (in Chinese), 1994, 36, 720 726.

Zhao, Y., Xu, Q., Huang, X., Guo, X., Tao, S., 2009. Differences of modern pollen assemblages from lake sediments and surface soils in arid and semi-arid China and their significance for pollen-based quantitative climate reconstruction. Rev. Palaeobot. Palynol. $156,519-524$.

Ziegler, P.A., 1992. European Cenozoic rift system. Tectonophysics 208, 91-111. 


\section{Web references}

Meteorological data at the station of Brest - https://fr.climate-data.org/location/5620/. 2017

Observatoire de l'agriculture du Finistère - http://www.synagri.com/synagri/act-observatoirede-lagriculture-du-finistere-2015-indicateurs-de-developpement-durable-parution-du-premiernumero. 2017

Corine Land Cover map 2006 - http://www.geoportail.gouv.fr

\section{Table captions}

Table 1: Location of surface sediment samples, depths and deposit environments.

Table 2: Location of mosses sampling areas.

Table 3: Pollen taxa occurrences, average, maximum percentages, and standard deviation for each palynological study sample. For each taxa, pollen occurrences in the overall marine surface sediments (number, average percentage, standard deviation, maximum percentage) and in the overall moss samples, with the vegetation-type attribution.

Table 4: Non-pollen palynomorph taxa occurrences, average and maximum percentages, and standard deviation for each palynological study sample. 


\section{Figure captions}

Figure 1: Location of the Bay of Brest (BB) in northwestern France. a) Location of sampling sites on a topographical map of the BB (after Gregoire et al., 2016). Black triangles: surface sediment samples; green crosses: moss samples. b) Present-day climate data with an ombrothermic diagram (temperatures and precipitations) and wind rose showing prevailing wind directions, strength $(\mathrm{km} / \mathrm{h})$ in course of one year averaged over 10 years. (Sources: station of Brest-Guipavas "climate-data.org", and Météo France, respectively). c) Map of surface currents speed (m/s) across the BB (source: SHOM).

Figure 2: Continental vegetation cover on the watersheds of the Bay of Brest (BB). a) Map of different types of vegetation found on BB watersheds (from Corine Land Cover database), extracted thanks to Arcgis software (ESRI 2011. ArcGIS Desktop: Release 10. Redlands, CA: Environmental Systems Research Institute). b) Conversion of the surfaces covered by these types of vegetation in $\%$ of the total surface. c-c') Land cover proportions of vegetation types for the "Finistere" department (c) and detail distribution of crops in agricultural areas (c') plotted in pie charts from the "Chambre d'agriculture du Finistère" data. (The color version is available online).

Figure 3: Pollen spectra (major taxa higher than $2 \%$ in at least one sample are represented) in a) surface sediment samples from the Bay of Brest (BB), and b) continental mosses collected from the periphery of the BB. 
Figure 4: Pie charts of average pollen percentages (taxa grouped in vegetation-types; see Table 3) in surface sediment and moss samples.

Figure 5: Modern dinocyst records in the Bay of Brest (BB): a) Diagram showing dinocyst concentrations (total and specific) as well as the dinocyst / pollen ratio, and b) Distribution map of total dinocyst concentrations in modern BB sediments (41 surface sediments) performed with the ArcGIS software using the Inverse Distance Weighted method (interpolation between different pointers done by averaging values of sample data points in the neighborhood with values becoming higher from bottom to top and from right to left).

Figure 6: Distribution maps of selected pollen taxa across the Bay of Brest (BB, 41 surface sediments) performed with the ArcGIS software using the Inverse Distance Weighted method (interpolation between different pointers done by averaging values of sample data points in the neighborhood with values becoming higher from bottom to top and from right to left). 
Table 1

\begin{tabular}{|c|c|c|c|c|}
\hline Core name & Latitude & Longitude & Depth (m) & $\begin{array}{c}\text { Sedimentary } \\
\text { context } \\
\text { (Gregoire et al., } \\
\text { 2015) }\end{array}$ \\
\hline SRQ1-I01 & $48^{\circ} 24^{\prime} 40.86^{\prime \prime} \mathrm{N}$ & $4^{\circ} 20^{\prime} 0.993^{\prime \prime} \mathrm{W}$ & 4.4 & Mud \\
\hline SRQ1-I02 & $48^{\circ} 18^{\prime} 38.77^{\prime \prime} \mathrm{N}$ & $4^{\circ} 31^{\prime} 52.931^{\prime \prime} \mathrm{W}$ & 11.6 & Mud \\
\hline SRQ1-I03 & $48^{\circ} 18^{\prime} 1.152^{\prime \prime} \mathrm{N}$ & $4^{\circ} 32^{\prime} 55.427^{\prime \prime} \mathrm{W}$ & 3.9 & Sandy mud \\
\hline SRQ1-104 & $48^{\circ} 17^{\prime} 45.348^{\prime \prime} \mathrm{N}$ & $4^{\circ} 29^{\prime} 11.94^{\prime \prime} \mathrm{W}$ & 8.2 & Muddy sand \\
\hline SRQ1-105 & $48^{\circ} 17^{\prime} 26.34^{\prime \prime} \mathrm{N}$ & $4^{\circ} 29^{\prime} 36.959^{\prime \prime} \mathrm{W}$ & 7 & Sandy mud \\
\hline SRQ1-106 & $48^{\circ} 18^{\prime} 4.68^{\prime \prime} \mathrm{N}$ & $4^{\circ} 28^{\prime} 47.891^{\prime \prime} \mathrm{W}$ & 16.4 & Muddy sand \\
\hline SRQ1-I07 & $48^{\circ} 19^{\prime} 36.012^{\prime \prime} \mathrm{N}$ & $4^{\circ} 20^{\prime} 14.172^{\prime \prime} \mathrm{W}$ & 5.8 & Gravelly mud \\
\hline SRQ1-108 & $48^{\circ} 20^{\prime} 7.368^{\prime \prime} \mathrm{N}$ & $4^{\circ} 19^{\prime} 36.551^{\prime \prime} \mathrm{W}$ & 5.5 & Muddy gravel \\
\hline SRQ1-109 & $48^{\circ} 20^{\prime} 44.412^{\prime \prime} \mathrm{N}$ & $4^{\circ} 17^{\prime} 42.179^{\prime \prime} \mathrm{W}$ & 4.4 & Mud \\
\hline SRQ1-I10 & $48^{\circ} 20^{\prime} 24.936^{\prime \prime} \mathrm{N}$ & $4^{\circ} 20^{\prime} 21.102^{\prime \prime} W$ & 6.3 & Mud \\
\hline SRQ1-I11 & $48^{\circ} 20^{\prime} 23.028^{\prime \prime} \mathrm{N}$ & $4^{\circ} 21^{\prime} 40.787^{\prime \prime} \mathrm{W}$ & 6.8 & Mud \\
\hline SRQ1-I12 & $48^{\circ} 17^{\prime} 44.268^{\prime \prime} \mathrm{N}$ & $4^{\circ} 15^{\prime} 12.24^{\prime \prime} \mathrm{W}$ & 16.7 & Sandy mud \\
\hline SRQ1-I13 & $48^{\circ} 18^{\prime} 31.14^{\prime \prime} \mathrm{N}$ & $4^{\circ} 17^{\prime} 31.74^{\prime \prime} \mathrm{W}$ & 3.3 & Gravelly mud \\
\hline SRQ1-I14 & $48^{\circ} 18^{\prime} 20.808^{\prime \prime} \mathrm{N}$ & $4^{\circ} 18^{\prime} 15.912^{\prime \prime} \mathrm{W}$ & 3.6 & Muddy gravel \\
\hline SRQ1-I15 & $48^{\circ} 18^{\prime} 34.452^{\prime \prime} \mathrm{N}$ & $4^{\circ} 18^{\prime} 50.796^{\prime \prime} \mathrm{W}$ & 19 & Mud and sandy \\
\hline SRQ1-I16 & $48^{\circ} 18^{\prime} 3.528^{\prime \prime} \mathrm{N}$ & $4^{\circ} 19^{\prime} 3.9^{\prime \prime} \mathrm{W}$ & 5.1 & Gravelly mud \\
\hline SRQ1-I17 & $48^{\circ} 22^{\prime} 49.512^{\prime \prime} \mathrm{N}$ & $4^{\circ} 26^{\prime} 15.359^{\prime \prime} \mathrm{W}$ & 5.9 & Mud and sandy \\
\hline SRQ1-I18 & $48^{\circ} 22^{\prime} 42.06^{\prime \prime} \mathrm{N}$ & $4^{\circ} 26^{\prime} 10.68^{\prime \prime} \mathrm{W}$ & 9.9 & Mud and sandy \\
\hline SRQ1-I19 & $48^{\circ} 22^{\prime} 21.18^{\prime \prime} \mathrm{N}$ & $4^{\circ} 28^{\prime} 8.687^{\prime \prime} \mathrm{W}$ & 6.4 & Sandy mud \\
\hline SRQ1-120 & $48^{\circ} 18^{\prime} 55.44^{\prime \prime} \mathrm{N}$ & $4^{\circ} 23^{\prime} 15.072^{\prime \prime} \mathrm{W}$ & 5.9 & Gravelly mud \\
\hline SRQ1-I21 & $48^{\circ} 19^{\prime} 11.1^{\prime \prime} \mathrm{N}$ & $4^{\circ} 21^{\prime} 43.487^{\prime \prime} \mathrm{W}$ & 11.4 & Sandy mud \\
\hline SRQ1-122 & $48^{\circ} 18^{\prime} 44.388^{\prime \prime} \mathrm{N}$ & $4^{\circ} 21^{\prime} 58.392^{\prime \prime} \mathrm{W}$ & 4.6 & Gravelly mud \\
\hline SRQ1-I23 & $48^{\circ} 17^{\prime} 24^{\prime \prime} \mathrm{N}$ & $4^{\circ} 20^{\prime} 52.008^{\prime \prime} \mathrm{W}$ & 7.9 & Gravelly mud \\
\hline SRQ1-124 & $48^{\circ} 17^{\prime} 27.348^{\prime \prime} \mathrm{N}$ & $4^{\circ} 20^{\prime} 48.418^{\prime \prime} \mathrm{W}$ & 10 & Sandy mud \\
\hline SRQ1-I25 & $48^{\circ} 16^{\prime} 53.868^{\prime \prime} \mathrm{N}$ & $4^{\circ} 23^{\prime} 49.632^{\prime \prime} \mathrm{W}$ & 7.4 & Gravelly mud \\
\hline SRQ1-I26 & $48^{\circ} 17^{\prime} 15.288^{\prime \prime} \mathrm{N}$ & $4^{\circ} 23^{\prime} 37.571^{\prime \prime} \mathrm{W}$ & 16 & Mud \\
\hline SRQ1-127 & $48^{\circ} 17^{\prime} 34.26^{\prime \prime} \mathrm{N}$ & $4^{\circ} 24^{\prime} 20.087^{\prime \prime} \mathrm{W}$ & 13.4 & Gravelly mud \\
\hline SRQ1-128 & $48^{\circ} 17^{\prime} 47.04^{\prime \prime} \mathrm{N}$ & $4^{\circ} 25^{\prime} 43.247^{\prime \prime} \mathrm{W}$ & 14.7 & Sandy mud \\
\hline SRQ1-I30 & $48^{\circ} 19^{\prime} 18.588^{\prime \prime} \mathrm{N}$ & $4^{\circ} 32^{\prime} 13.02^{\prime \prime} \mathrm{W}$ & 5.2 & Mud and sandy \\
\hline SRQ1-I31 & $48^{\circ} 21^{\prime} 18.468^{\prime \prime} \mathrm{N}$ & $4^{\circ} 27^{\prime} 32.157^{\prime \prime} \mathrm{W}$ & 8.5 & Muddy sand \\
\hline SRQ1-132 & $48^{\circ} 22^{\prime} 41.88^{\prime \prime} \mathrm{N}$ & $4^{\circ} 27^{\prime} 5.615^{\prime \prime} \mathrm{W}$ & 5.2 & Sandy mud \\
\hline AL2013-101 & $48^{\circ} 14^{\prime} 9.96^{\prime \prime} \mathrm{N}$ & $4^{\circ} 14^{\prime} 2.759^{\prime \prime} \mathrm{W}$ & 4.5 & Sandy mud \\
\hline AL2013-102 & $48^{\circ} 13^{\prime} 15.312^{\prime \prime} \mathrm{N}$ & $4^{\circ} 15^{\prime} 32.687^{\prime \prime} \mathrm{W}$ & 4.5 & Mud and sandy \\
\hline AL2013-103 & $48^{\circ} 13^{\prime} 9.3^{\prime \prime} \mathrm{N}$ & $4^{\circ} 15^{\prime} 26.244^{\prime \prime} \mathrm{W}$ & 5.4 & Muddy sand \\
\hline AL2013-104 & $48^{\circ} 12^{\prime} 21.96^{\prime \prime} \mathrm{N}$ & $4^{\circ} 17^{\prime} 58.307^{\prime \prime} \mathrm{W}$ & 2.7 & Sandy mud \\
\hline AL2013-106 & $48^{\circ} 13^{\prime} 46.956^{\prime \prime} \mathrm{N}$ & $4^{\circ} 14^{\prime} 55.248^{\prime \prime} \mathrm{W}$ & 3 & Gravelly muddy \\
\hline
\end{tabular}




\begin{tabular}{lcccc}
\hline AL2013-108 & $48^{\circ} 11^{\prime} 34.908^{\prime \prime} \mathrm{N}$ & $4^{\circ} 15^{\prime} 13.355^{\prime \prime} \mathrm{W}$ & 3.9 & Sandy mud \\
\hline AL2013-109 & $48^{\circ} 11^{\prime} 34.908^{\prime \prime} \mathrm{N}$ & $4^{\circ} 15^{\prime} 2.555^{\prime \prime} \mathrm{W}$ & 5.78 & Gravelly muddy \\
AL2013-I10 & $48^{\circ} 14^{\prime} 6.396^{\prime \prime} \mathrm{N}$ & $4^{\circ} 15^{\prime} 10.8^{\prime \prime} \mathrm{W}$ & 1 & Sandy mud \\
AL2013-I12 & $48^{\circ} 14^{\prime} 20.76^{\prime \prime} \mathrm{N}$ & $4^{\circ} 13^{\prime} 26.472^{\prime \prime} \mathrm{W}$ & 1 & Sandy mud \\
AL2013-I13 & $48^{\circ} 14^{\prime} 25.188^{\prime \prime} \mathrm{N}$ & $4^{\circ} 13^{\prime} 14.484^{\prime \prime} \mathrm{W}$ & $?$ & Gravelly mud \\
\hline
\end{tabular}


Table 2

\begin{tabular}{ccc}
\hline Station name & Latitude & Longitude \\
\hline Pointe de Dinan & $48^{\circ} 14^{\prime} 14.27^{\prime \prime} \mathrm{N}$ & $4^{\circ} 33^{\prime} 32.40^{\prime \prime} \mathrm{W}$ \\
Pointe de Dinan 2 & $48^{\circ} 14^{\prime} 14.27^{\prime \prime} \mathrm{N}$ & $4^{\circ} 33^{\prime} 32.40^{\prime \prime} \mathrm{W}$ \\
Bay of Goulien & $48^{\circ} 15^{\prime} 03.27^{\prime \prime} \mathrm{N}$ & $4^{\circ} 32^{\prime} 31.58^{\prime \prime} \mathrm{W}$ \\
Fraternité - Roscanvel & $48^{\circ} 18^{\prime} 33.1^{\prime \prime} \mathrm{N}$ & $4^{\circ} 33^{\prime} 57.1^{\prime \prime} \mathrm{W}$ \\
Quélern - Persuel & $48^{\circ} 17^{\prime} 30.0^{\prime \prime} \mathrm{N}$ & $4^{\circ} 33^{\prime} 01.1^{\prime \prime} \mathrm{W}$ \\
Bay of Fret & $48^{\circ} 17^{\prime} 07.00^{\prime \prime} \mathrm{N}$ & $4^{\circ} 28^{\prime} 27.4^{\prime \prime} \mathrm{W}$ \\
Pen Ar Vir & $48^{\circ} 17^{\prime} 17.5^{\prime \prime} \mathrm{N}$ & $4^{\circ} 25^{\prime} 41.1^{\prime \prime} \mathrm{W}$ \\
Bay of Poulmic & $48^{\circ} 16^{\prime} 36.9^{\prime \prime} \mathrm{N}$ & $4^{\circ} 21^{\prime} 13.7^{\prime \prime} \mathrm{W}$ \\
National forest Landévennec & $48^{\circ} 17^{\prime} 29.5^{\prime \prime} \mathrm{N}$ & $4^{\circ} 18^{\prime} 44.5^{\prime \prime} \mathrm{W}$ \\
Keramenez & $48^{\circ} 19^{\prime} 58.2^{\prime \prime} \mathrm{N}$ & $4^{\circ} 24^{\prime} 30.9^{\prime \prime} \mathrm{W}$ \\
Kernizi & $48^{\circ} 21^{\prime} 50.9^{\prime \prime} \mathrm{N}$ & $4^{\circ} 25^{\prime} 39.3^{\prime \prime} \mathrm{W}$ \\
Pointe du Diable & $48^{\circ} 21^{\prime} 18.6^{\prime \prime} \mathrm{N}$ & $4^{\circ} 33^{\prime} 31.8^{\prime \prime} \mathrm{W}$ \\
\hline
\end{tabular}


Table 3

\begin{tabular}{|c|c|c|c|c|c|c|}
\hline \multirow[b]{2}{*}{ Pollen taxa } & \multicolumn{4}{|c|}{ Surface sediment samples } & \multirow{2}{*}{\begin{tabular}{|c|}
$\begin{array}{c}\text { Moss } \\
\text { samples }\end{array}$ \\
$\begin{array}{c}\text { samples } \\
\text { occurrences }\end{array}$
\end{tabular}} & \multirow[b]{2}{*}{$\begin{array}{l}\text { Vegetation } \\
\text { type }\end{array}$} \\
\hline & occurences & $\begin{array}{c}\text { Average } \\
\text { percentages } \\
(\%)\end{array}$ & $\begin{array}{l}\text { Standard } \\
\text { deviation }\end{array}$ & \begin{tabular}{|c|} 
Maximum \\
percentage \\
$(\%)$
\end{tabular} & & \\
\hline Acacia & $x$ & $x$ & $x$ & $x$ & 3 & Forest \\
\hline Alnus & 41 & 8,28 & 4,2 & 26 & 9 & $\begin{array}{l}\text { Riparian } \\
\text { forest }\end{array}$ \\
\hline Apiaceae & 3 & 0,21 & 0,4 & 6,7 & 1 & Herbaceous \\
\hline Asteroideae & 12 & 0,39 & 0,6 & 2,2 & 7 & Herbaceous \\
\hline Betula & 19 & 1,26 & 1,4 & 5,6 & 9 & Forest \\
\hline Brassicaceae & 28 & 1,71 & 1,4 & 5,6 & 10 & Herbaceous \\
\hline Cannabis & 1 & 0,02 & 0 & 1 & $X$ & Herbaceous \\
\hline Caryophyllaceae & 2 & 0,04 & 0,1 & 1 & 5 & Forest \\
\hline Castanea & 31 & 2,49 & 1,7 & 7,3 & 6 & Herbaceous \\
\hline Centaurea & $\mathrm{X}$ & $\mathrm{X}$ & $\mathrm{x}$ & $\mathrm{x}$ & 1 & Herbaceous \\
\hline Chenopodiaceae & 27 & 1,81 & 1,3 & 8,3 & & Herbaceous \\
\hline Cichorioideae & 19 & 1,02 & 1,1 & 5,6 & 8 & Herbaceous \\
\hline Corylus & 41 & 10,94 & 3,3 & 20 & 12 & Forest \\
\hline Cupressaceae & 12 & 0,8 & 1,4 & 5,6 & 1 & Forest \\
\hline Cyperaceae & 4 & 0,10 & 0,2 & 1,5 & $x$ & Herbaceous \\
\hline Cytisus & 2 & 0,05 & 0,1 & 1,1 & $x$ & Herbaceous \\
\hline Dactylis & $x$ & $x$ & $\mathrm{x}$ & $x$ & 1 & Herbaceous \\
\hline Dipsacaceae & $x$ & $x$ & $\mathrm{X}$ & $x$ & 6 & Herbaceous \\
\hline Ephedra & 1 & 0,02 & 0 & 1 & $x$ & Herbaceous \\
\hline Ericaceae & 14 & 0,52 & 0,7 & 2,2 & 7 & Herbaceous \\
\hline Fabaceae & 7 & 0,29 & 0,5 & 4,5 & $x$ & Herbaceous \\
\hline Fagopyrum & 1 & 0,02 & 0 & 0,9 & $x$ & Crops \\
\hline Fagus & 11 & 0,34 & 0,5 & 2 & 4 & Forest \\
\hline Filipendula & 1 & 0,02 & 0 & 0,9 & $x$ & Herbaceous \\
\hline Fraxinus & 21 & 1,05 & 1,1 & 7,1 & 9 & Forest \\
\hline Geranium & 1 & 0,02 & 0 & 1 & $x$ & Herbaceous \\
\hline Hedera & 13 & 0,65 & 0,9 & 5,6 & 8 & Forest \\
\hline Ilex & 14 & 0,48 & 0,6 & 4 & 6 & Forest \\
\hline Juglans & $x$ & $x$ & $x$ & $x$ & 1 & Forest \\
\hline Lamiaceae & $\mathrm{X}$ & $\mathrm{x}$ & $\mathrm{X}$ & $\mathrm{X}$ & 1 & Herbaceous \\
\hline Mercurialis & 9 & 0,35 & 0,5 & 3,8 & 4 & Herbaceous \\
\hline Nuphar & $x$ & $x$ & $x$ & $x$ & 1 & Herbaceous \\
\hline Pinus & 41 & 12,91 & 4,5 & 33 & 12 & Forest \\
\hline Plantago coronopus & 11 & 0,41 & 0,6 & 3,2 & 2 & Herbaceous \\
\hline Plantago lanceolata & 6 & 0,29 & 0,5 & 3,5 & 2 & Herbaceous \\
\hline Plantago maritima & 21 & 1,10 & 1,2 & 5,6 & 7 & Herbaceous \\
\hline Plantago spp & 2 & 0,05 & 0,1 & 1 & 1 & Herbaceous \\
\hline
\end{tabular}




\begin{tabular}{|ccccccc}
\hline Poaceae & 41 & 15 & 8 & 38,9 & 12 & Herbaceous \\
\hline Cerealia type & 25 & 1,1 & 1,2 & 4,3 & 5 & Crops \\
\hline Polygonum aviculare & 1 & 0,02 & 0 & 1 & $\mathrm{X}$ & Herbaceous \\
\hline Populus & 13 & 0,5 & 0,7 & 3 & 6 & Forest \\
\hline Potamogeton & 5 & 0,23 & 0,4 & 2,9 & $\mathrm{X}$ & Herbaceous \\
\hline Primulaceae & 4 & 0,17 & 0,3 & 4,4 & $\mathrm{X}$ & Herbaceous \\
\hline Quercus & 41 & 25,69 & 7 & 45 & 12 & Forest \\
\hline Quercus ilex & 2 & 0,04 & 0,1 & 0,9 & $\mathrm{X}$ & Forest \\
\hline Radiola linoides & 1 & 0,02 & 0 & 1 & $\mathrm{X}$ & Herbaceous \\
\hline Rannunculaceae & 2 & 0,09 & 0,2 & 2 & 3 & Herbaceous \\
\hline Rosaceae & 3 & 0,2 & 0,6 & 1,9 & 4 & Herbaceous \\
\hline Rubiaceae & $\mathrm{X}$ & $\mathrm{X}$ & $\mathrm{X}$ & $\mathrm{X}$ & 1 & Herbaceous \\
\hline Rumex & 10 & 0,36 & 0,6 & 2 & $\mathrm{X}$ & Herbaceous \\
\hline Salix & 22 & 1,51 & 1,6 & 9,7 & 2 & Riparian $\mathrm{f}$ \\
\hline Saxifraga & 5 & 0,24 & 0,4 & 2,8 & $\mathrm{X}$ & Herbaceous \\
\hline Scrofulariaceae & 1 & 0,02 & 0 & 1 & $\mathrm{X}$ & Herbaceous \\
\hline Taraxacum & $\mathrm{X}$ & $\mathrm{X}$ & $\mathrm{X}$ & $\mathrm{X}$ & 1 & Herbaceous \\
\hline Tilia & 1 & 0,02 & 0 & 0,8 & $\mathrm{X}$ & Forest \\
\hline Trifolium & $\mathrm{X}$ & $\mathrm{X}$ & $\mathrm{X}$ & $\mathrm{X}$ & 2 & Herbaceous \\
\hline Typha / Sparganium & $\mathrm{X}$ & $\mathrm{X}$ & $\mathrm{X}$ & $\mathrm{X}$ & 1 & Herbaceous \\
\hline Type-Ulex & 1 & 0,05 & 0,1 & 2 & 3 & Herbaceous \\
\hline Ulmus & 33 & 2,04 & 1,4 & 7,8 & 3 & Forest \\
\hline Urticaceae & 15 & 1,12 & 1,5 & 7,4 & 6 & Herbaceous \\
\hline Valerianaceae & $\mathrm{X}$ & $\mathrm{X}$ & $\mathrm{X}$ & $\mathrm{X}$ & 1 & Herbaceous \\
\hline
\end{tabular}


Table 4:

\begin{tabular}{|c|c|c|c|c|c|c|}
\hline $\begin{array}{l}\text { Dinocyst } \\
\text { Taxa }\end{array}$ & $\begin{array}{l}\text { Occurrences } \\
\text { in marine } \\
\text { samples }\end{array}$ & $\begin{array}{c}\text { Average } \\
\text { percentages } \\
(\%)\end{array}$ & $\begin{array}{c}\text { Maximum } \\
\text { percentage } \\
(\%)\end{array}$ & $\begin{array}{c}\text { Other NPP } \\
\text { Taxa }\end{array}$ & $\begin{array}{l}\text { Occurrences } \\
\text { in marine } \\
\text { samples }\end{array}$ & $\begin{array}{l}\text { Occurrences } \\
\text { in moss } \\
\text { samples }\end{array}$ \\
\hline $\begin{array}{l}\text { Ataxodinium } \\
\text { choane }\end{array}$ & 1 & 0 & 9 & Trilete spore & 37 & 4 \\
\hline $\begin{array}{l}\text { Lingulodinium } \\
\text { machaerophorum }\end{array}$ & 29 & 25 & 100 & $\begin{array}{l}\text { Monolete } \\
\text { spore }\end{array}$ & 32 & 3 \\
\hline $\begin{array}{l}\text { Operculodinium } \\
\text { centrocarpum }\end{array}$ & 8 & 2 & 27 & Macrospore & 16 & 2 \\
\hline $\begin{array}{l}\text { Operculodinium } \\
\text { longispinigerum }\end{array}$ & 1 & 0 & 10 & $\begin{array}{l}\text { Polypodium } \\
\text { spore }\end{array}$ & 27 & 4 \\
\hline Spiniferites belerius & 19 & 11 & 50 & $\begin{array}{l}\text { Asplenium } \\
\text { spore }\end{array}$ & 3 & 3 \\
\hline Spiniferites bentorii & 36 & 37 & 75 & Woodsia spore & 1 & 1 \\
\hline $\begin{array}{l}\text { Spiniferites } \\
\text { delicatus }\end{array}$ & 4 & 2 & 50 & $\begin{array}{l}\text { Foraminiferal } \\
\text { linings }\end{array}$ & 35 & 0 \\
\hline $\begin{array}{c}\text { Spiniferites } \\
\text { membranaceus }\end{array}$ & 22 & 11 & 50 & Microalgae & 26 & 0 \\
\hline $\begin{array}{c}\text { Spiniferites } \\
\text { mirabilis }\end{array}$ & 2 & 0 & 8 & $\begin{array}{l}\text { Radiosperma } \\
\text { corbiferum }\end{array}$ & 1 & 0 \\
\hline $\begin{array}{l}\text { Spiniferites } \\
\text { ramosus }\end{array}$ & 1 & 0 & 8 & Euglypha spp & 2 & 11 \\
\hline $\begin{array}{c}\text { Cyst of } \\
\text { Pentapharsodinium } \\
\text { dalei }\end{array}$ & 5 & 1 & 14 & Concentricystes & 1 & 0 \\
\hline \multirow[t]{3}{*}{$\begin{array}{c}\text { Selenopemphix } \\
\text { quanta }\end{array}$} & 6 & 1 & 18 & Prasinophyceae & 1 & 0 \\
\hline & & & & Tintinnid & 2 & 0 \\
\hline & 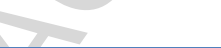 & & & Cyclopyxis spp & 0 & 6 \\
\hline
\end{tabular}



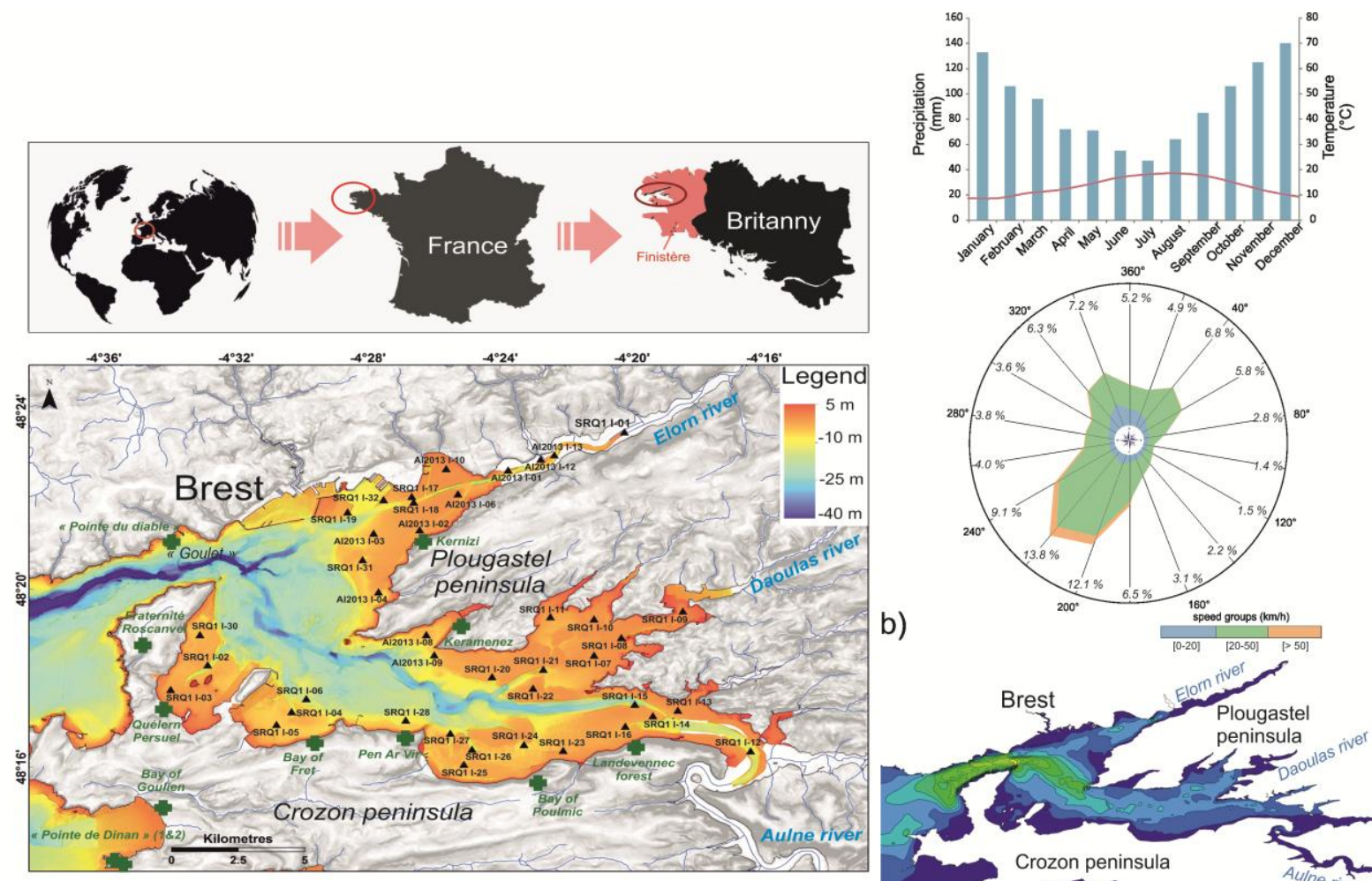

a)

b)
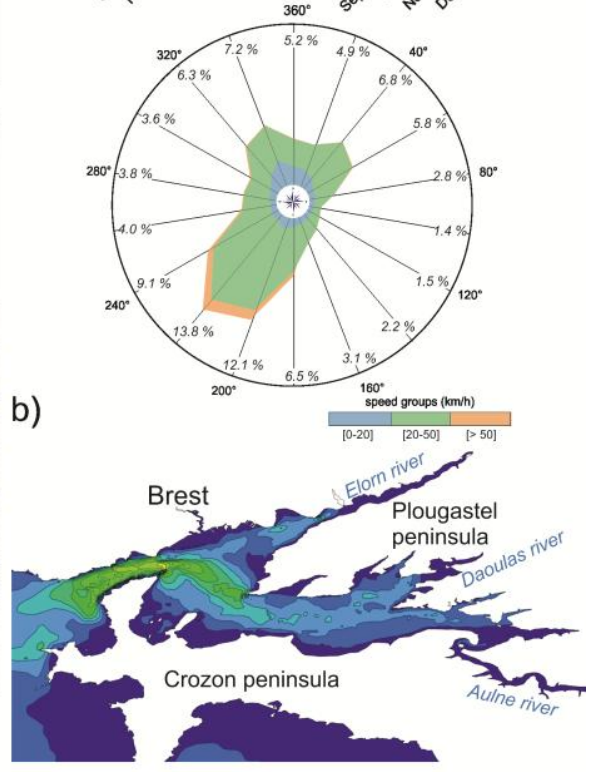

C) $1 \mathrm{~m} / \mathrm{s}$

$0 \mathrm{~m} / \mathrm{s}$

Figure 1 


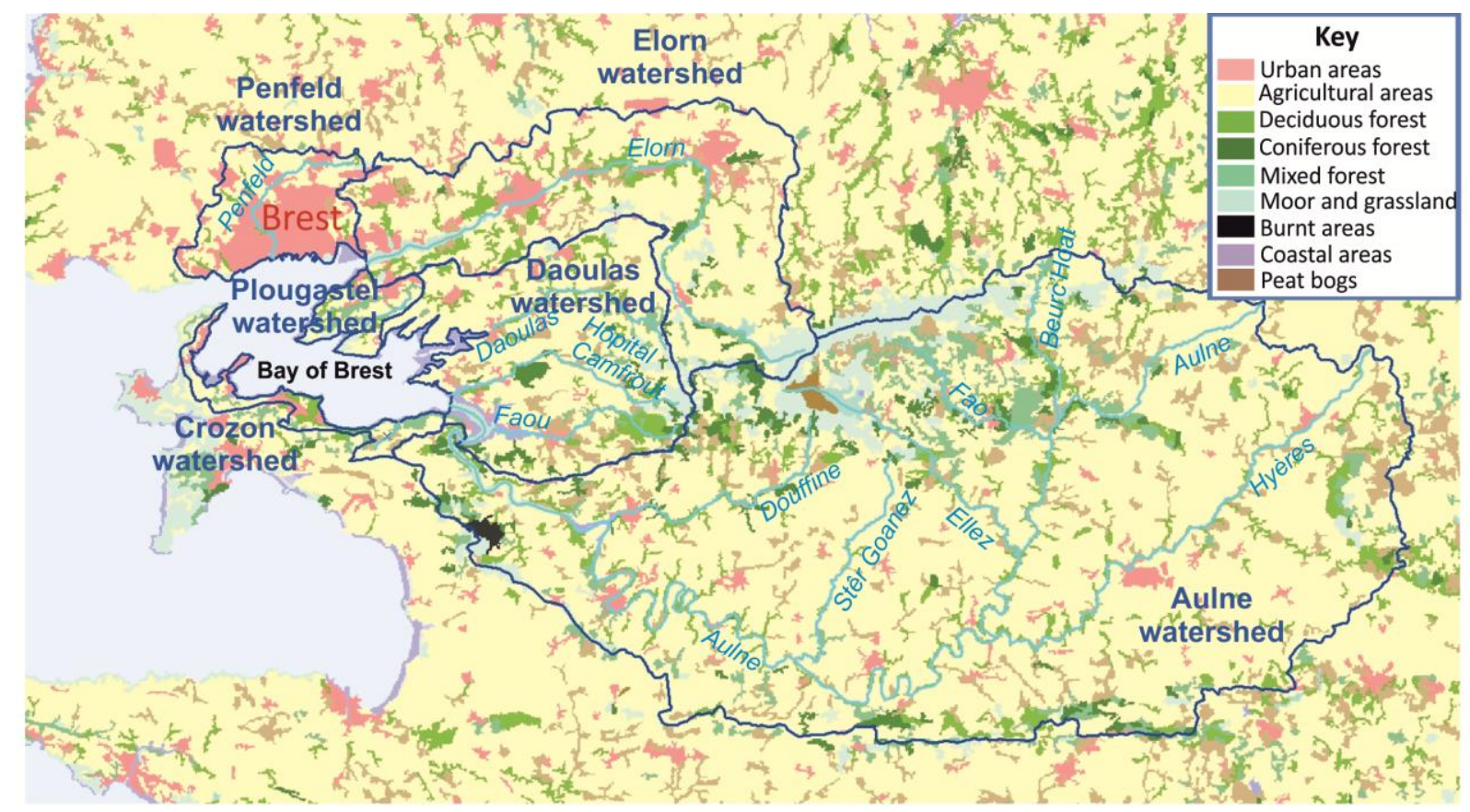

a.

source : European union - SOeS, Corine Land Cover, 2006

\section{Land cover on the Bay of Brest watersheds}

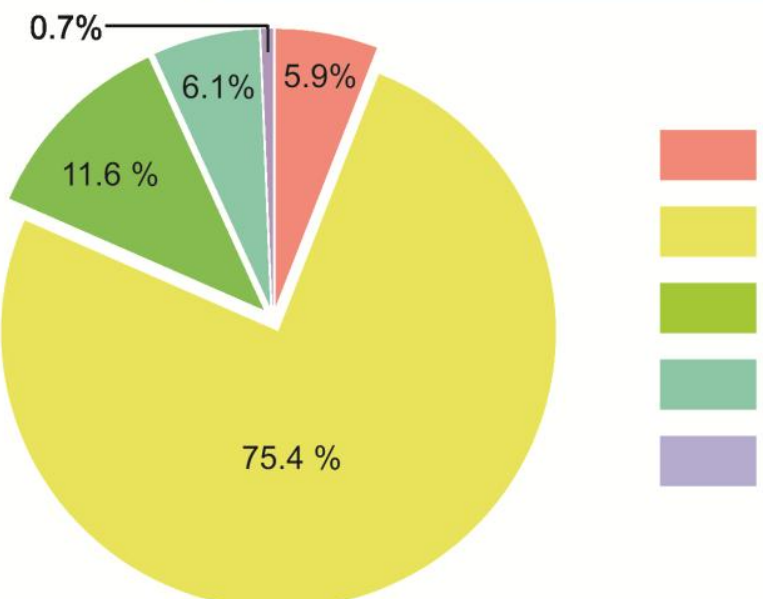

Urban areas

Agricultural areas

Woodlands (Deciduous+Coniferous)

Moor and grassland

Coastal areas

b.
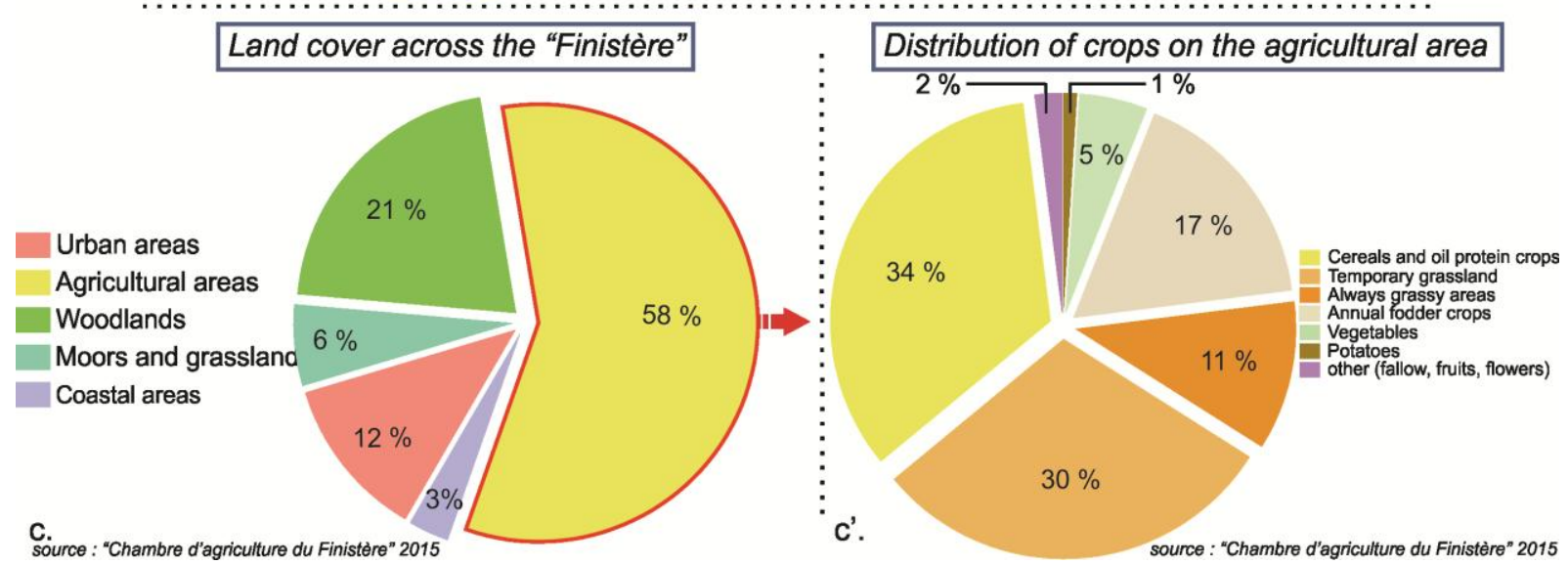
Figure 2

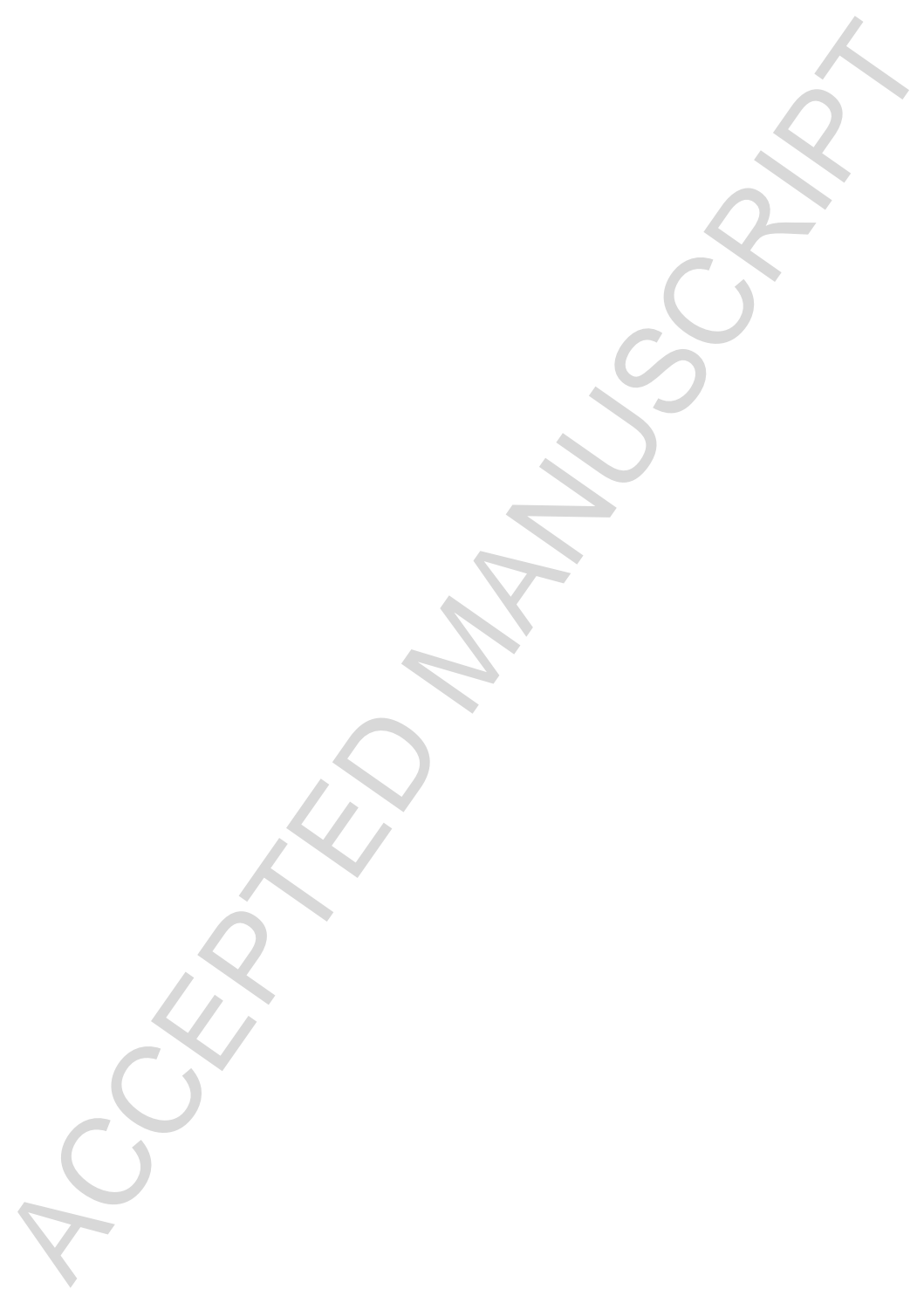




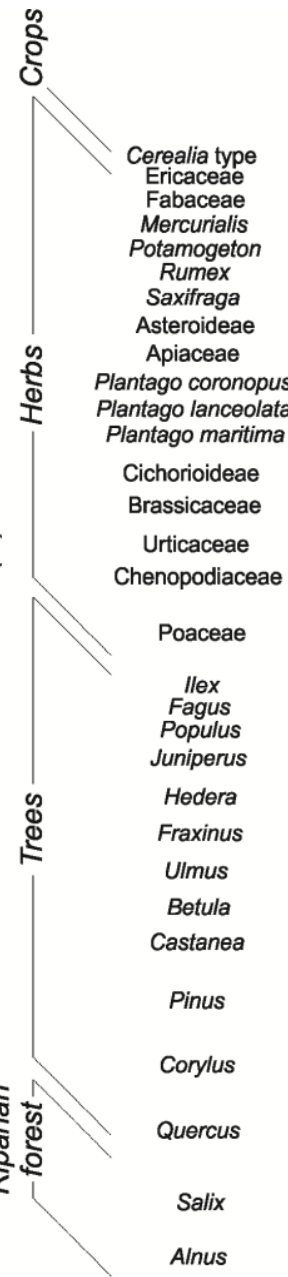

a)

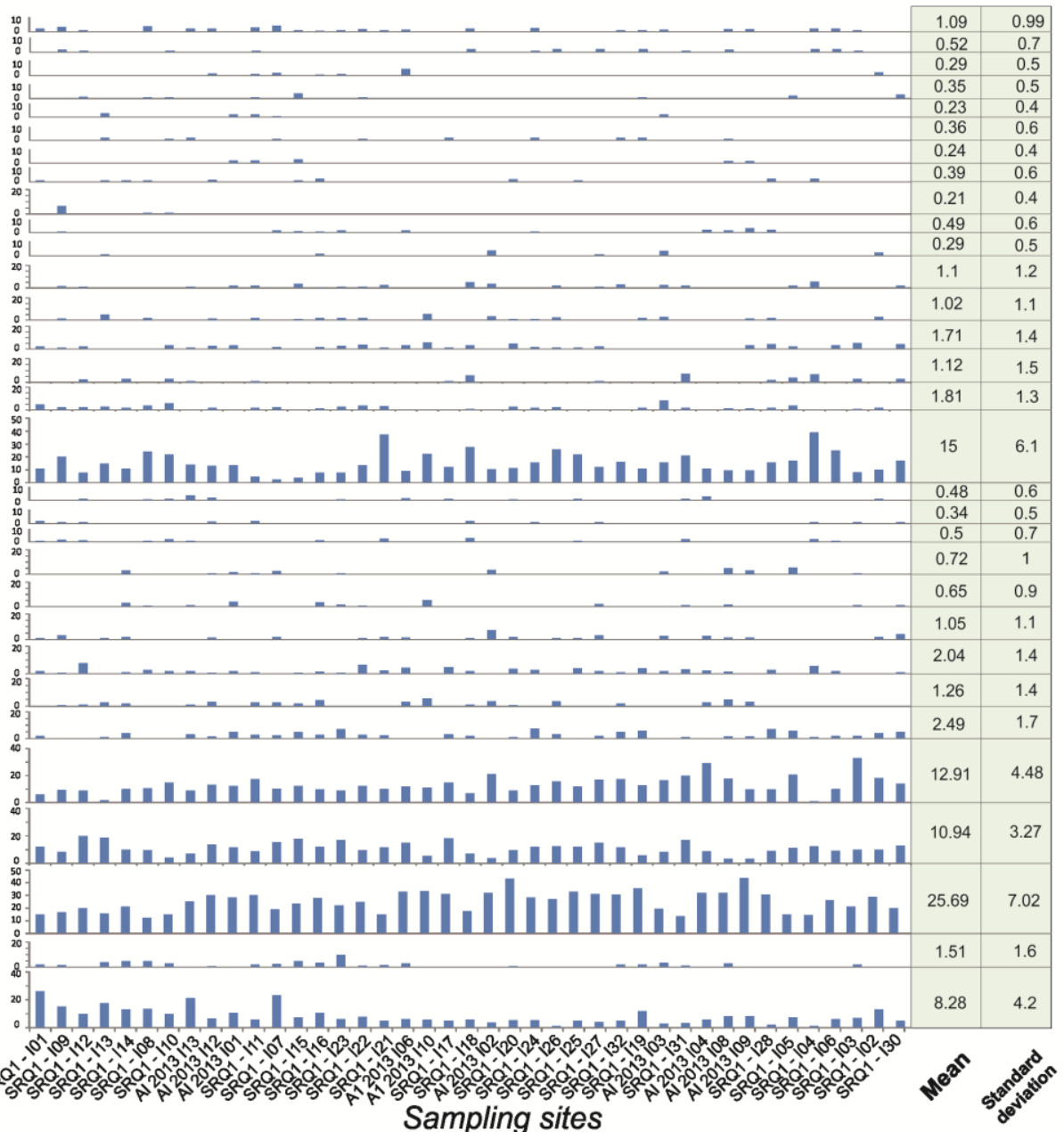

a)

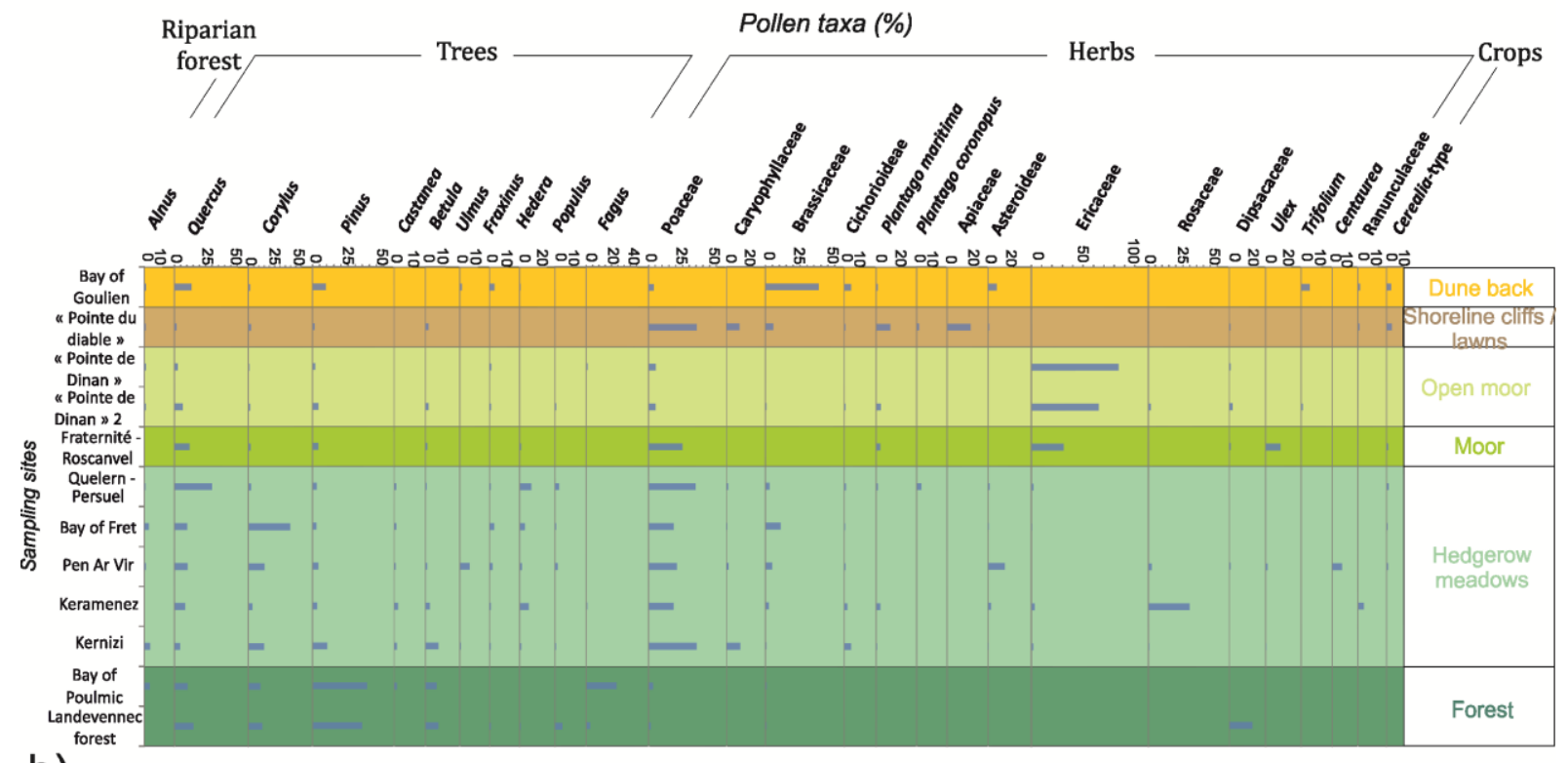

b) 
Figure 3

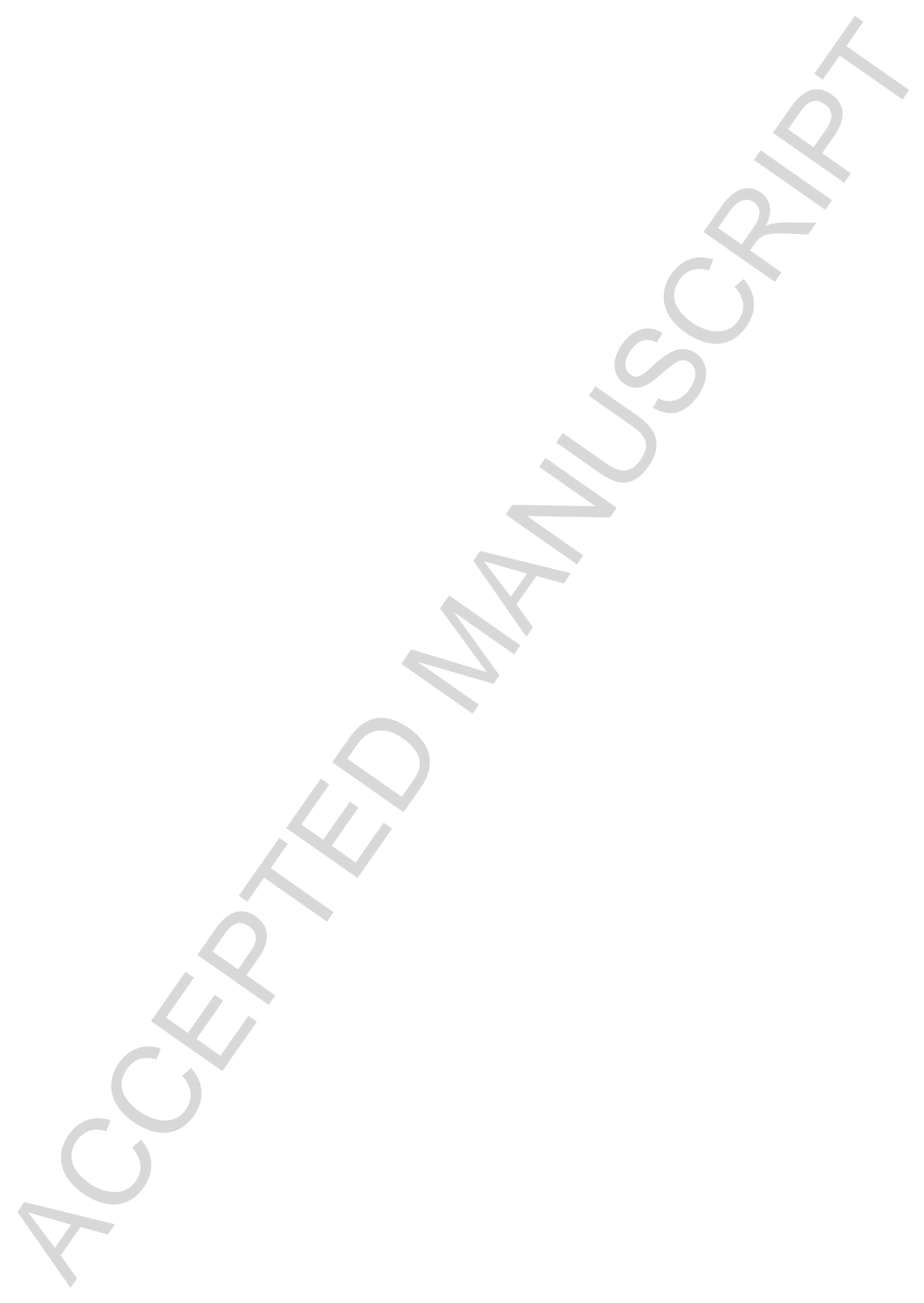




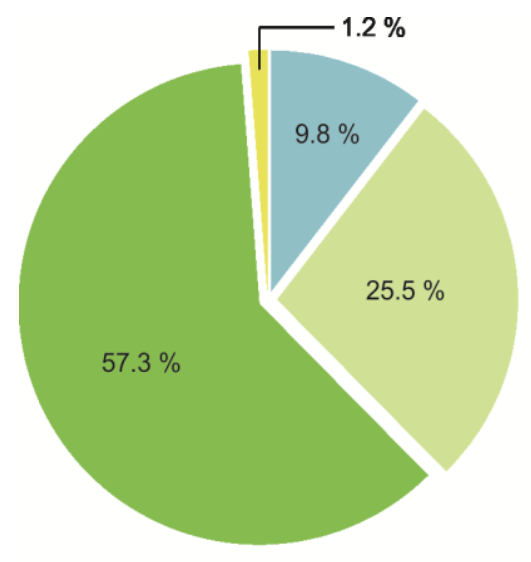

Sediment samples

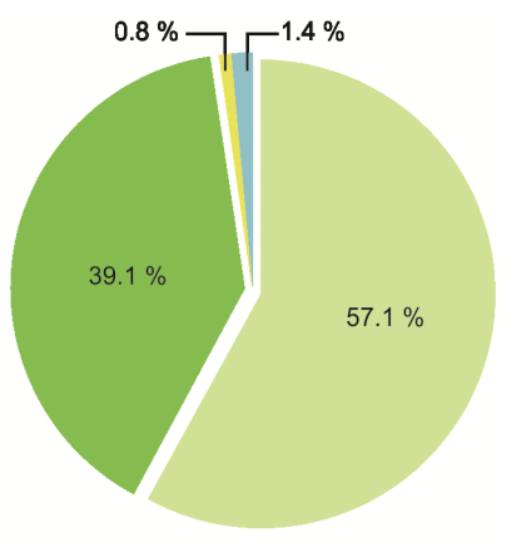

Moss samples
Riparian forest

Herbaceous

Forest

Crops

Figure 4 


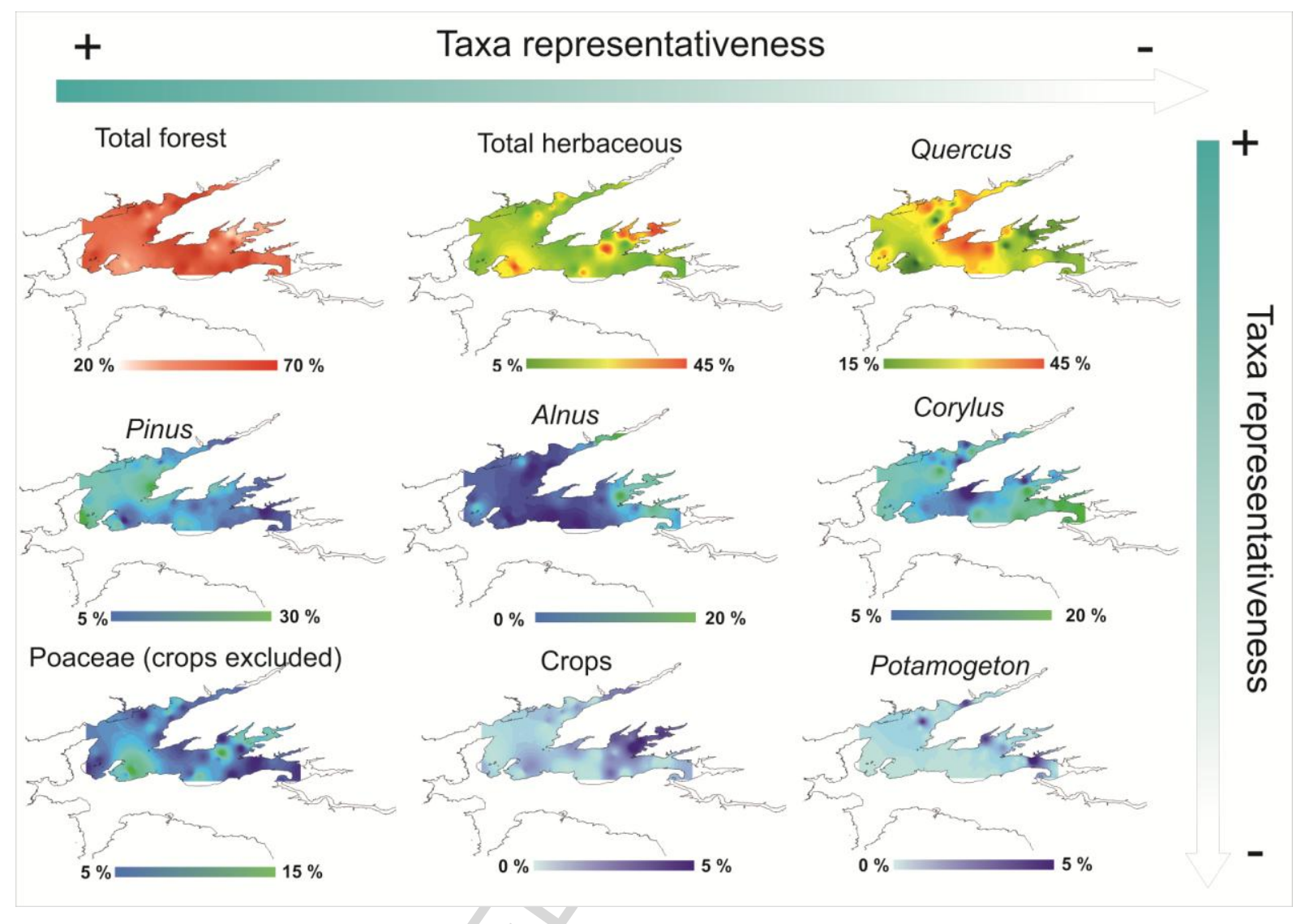

Figure 5 
Dinocyst concentrations

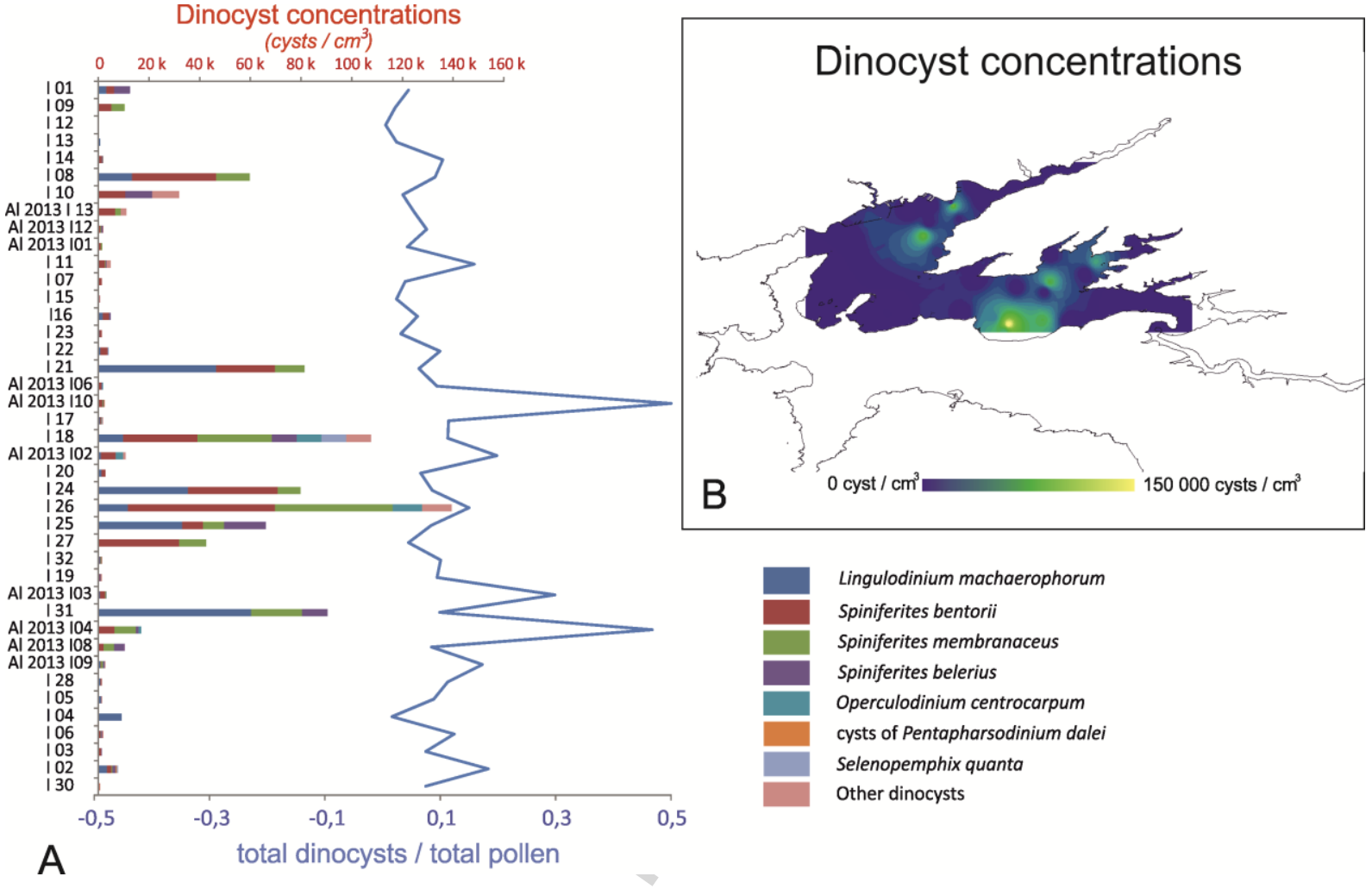

Figure 6 


\section{Highlights}

- Modern palynological (pollen, dinocysts) investigations in a NW French estuary

- Distortion between pollen taxa percentages and vegetation cover estimated on land

- Overestimation (/underestimation) of tree (/herbaceous) taxa in marine sediments

- Alnus as a potential proxy for fluvial Holocene palaeo-discharge 